\title{
THE INTERNAL POWERS OF THE CHIEF JUSTICE: THE NINETEENTH-CENTURY LEGACY
}

\author{
G. EDWARD WHITE ${ }^{\dagger}$ \\ INTRODUCTION
}

The literature on the role of the Chief Justice of the United States has been dominated by two stereotypes. One, perpetuated by Chief Justices themselves and generally endorsed by other Justices, is that the Chief Justice occupies the role of "first among equals," meaning that the powers of the Chief are largely formal, such as personifying the Court as an institution, as opposed to substantive, such as exercising disproportionate influence on colleagues. The phrase "among equals" in the stereotype is designed to emphasize the fact that nine Justices participate in the Court's decisions, that each of their votes is given equal weight, and that the central job tasks of the Chiefhearing arguments, deciding cases, writing opinions-are no different from those of the other Justices. ${ }^{1}$

The other stereotype, which has emerged primarily from social science literature, is that the Chief Justice has special opportunities to exercise "leadership" on the Court. This stereotype is connected to a theory of collective decision making in small groups. ${ }^{2}$ Although the

\footnotetext{
${ }^{\dagger}$ David and Mary Harrison Distinguished Professor of Law, University of Virginia School of Law. My thanks to Ted Ruger and Caleb Nelson for their comments on an earlier draft and to William E. Parker for research assistance.

${ }^{1}$ For references to this stereotype, see HENRY J. ABRAHAM, THE JUdicial Process 206 (4th ed. 1980) (discussing the role of the Chief Justice as primus inter pares); WALTER F. MURPHY, ELEMENTS OF JUdiCIAL STRATEGY 82 (1964) (noting that while the Justices are in theory "equal in authority," the Chief Justice does have some distinct authority not possessed by the other Justices); Alpheus Thomas Mason, The Chief Justice of the United States: Primus Inter Pares, 17 J. Pub. L. 20, 20 (1968) ("The Court is often referred to by the name of the man who occupies the center chair, implying that he puts his peculiar stamp on the Court's work."). The stereotype is captured by Chief Justice Salmon P. Chase, who wrote that "the Chief Justice . . . is but one of eight judges, each of whom has the same powers as himself. His judgment has no more weight, and his vote no more importance, than those of any of his brethren. He presides, and a good deal of extra labor is thrown upon him. That's all." Letter from Salmon P. Chase to John D. Van Buren (Mar. 25, 1868), quoted in Mason, supra, at 22.

${ }^{2}$ See MURPHY, supra note 1 , at 83 (" $[\mathrm{T}]$ here is an expectation that a titular leader will exert both task and social leadership ...."); David J. Danelski, The Influence of the Chief Justice in the Decisional Process of the Supreme Court, in AMERICAN COURT SYSTEMS
} 
Supreme Court is surely a unique small group-its decisions have very great authority and typically need to be given public legal justifications that are scrutinized by specialist commentators-it nonetheless resembles many other small groups in reaching its decisions collectively, through a deliberative process, and in following an established procedure, with formalized elements that facilitate that process. Moreover, the Chief Justice is, on most occasions, the "task leader" for the group's collective decision making ${ }^{3}$ : Chiefs set the agenda for the argument and discussion of cases and preside over the deliberations that lead to the rendering of a decision. In addition, Chiefs often control the assignment of opinions accompanying the Justices' dispositions of cases. This "task leadership" can be seen as equivalent to that of the chair of a committee.

Some social science scholarship has suggested that the "task leadership" functions of the Chief Justice also create opportunities for substantive leadership. ${ }^{4}$ Two functions have been singled out. First, in the hands of strategically minded Chiefs, the "task leadership" function of scheduling oral arguments and subsequent conference discussions can serve as a means of affecting the deliberative process for high-profile cases. Second, the "task leadership" function enables Chiefs, when they are part of the majority for a particular case, to strategically assign the opinion in that case to themselves or another member of the majority in accordance with substantive agendas.

486, 486-90 (Sheldon Goldman \& Austin Sarat eds., 2d ed. 1989) (describing the Chief Justice's outsize influence as leader of the small group); S. Sidney Ulmer, The Use of Power in the Supreme Court: The Opinion Assignments of Earl Warren, 1953-1960, 19 J. PuB. L. 49, 51 (1970) (discussing the power of the Chief Justice to assign opinions and the effect this has on collective decision making).

${ }^{3}$ The distinction between "task" and "social" leadership in small groups originated in Robert F. Bales, Task Roles and Social Roles in Problem-Solving Groups, in READINGS IN SOCIAL PSYCHOLOGY 437, 441 (Eleanor E. Maccoby et al. eds., 3d ed. 1958) (detailing "the hypothesis of two complementary leaders": a task-specialist and a social-emotional specialist); see also Walter F. Murphy, Courts As Small Groups, 79 HARV. L. REV. 1565, 1567 (1966) (discussing how a task leader "seeks to complete the present task in the most effective and efficient manner," while a social leader "seeks to provide the friendly atmosphere that eases cooperation").

${ }^{4}$ See, e.g., Danelski, supra note 2, at 487 (discussing how the Chief Justice can substantively exert influence); Walter F. Murphy, Marshaling the Court: Leadership, Bargaining, and the Judicial Process, 29 U. CHI. L. REv. 640, 642 (1962) (“[T]he task-social leadership dichotomy can ... put on a firmer empirical basis the common sense observation that a man who wishes to exert influence over his fellows can do so most effectively if he is both intellectually disciplined and tactful in interpersonal relations."); Ulmer, supra note 2, at 56 (discussing the opportunities for active leadership by the Chief Justice). 
The chief justiceship, in sum, brings with it a special seniority. The Chief personifies the Court in popular parlance. He also is, for better or worse, the Court's chief presiding officer. When social scientists speak of the Chief's "task leadership," they have these special seniority functions in mind. But there has been remarkably little discussion of the origins of these functions. Why did the agenda-setting and assignment powers devolve upon the chief justiceship? What is there about the office of Chief Justice that gives the occupant of that position powers which transcend two long-established customs of the Court, that seniority yields privileges and that seniority is a function exclusively of a Justice's length of service? How, in short, did the special seniority of the Chief Justice come into being?

This Article explores these questions. Part I considers why, as a historical matter, the chief justiceship was treated as a position distinct from that of the other justiceships, particularly since there was no discussion in the debates ratifying the Constitution of the Chief Justice's office or powers, and only one constitutional provision singles out the chief justiceship, declaring that the Chief Justice will preside at presidential impeachment trials. ${ }^{5}$ Part II explores the origins of the Chief's powers of controlling the Court's internal deliberations and of assigning opinions in cases, concluding, first, that neither one of those powers was historically inevitable; second, that the internal exercise of both powers has changed over the course of the Court's history; and third, and perhaps most significantly, that the Court's internal protocols governing its deliberative process have also changed. Finally, Part III asks to what extent the nineteenth-century legacy of the Chief Justice's internal powers has served to burden, or benefit, some twentieth- and twenty-first-century Chief Justices, and whether, notwithstanding the historical contingency and changing exercise of those powers, they can now be said to be dimensions of the office of Chief Justice of the United States that are cast in stone.

\section{The ORIGINS OF THE CHIEF JUSTICE'S SPECIAL SENIORITY}

\section{A. Early Assumptions About the Chief Justiceship}

Although the Constitution is virtually silent about the offices of the Chief Justice and the Associate Justices of the Supreme Court, the provision in Article I giving the Chief Justice power to preside over

\footnotetext{
${ }^{5}$ U.S. CONST. art. I, $\$ 3$ ("When the President of the United States is tried [for impeachment], the Chief Justice shall preside ....").
} 
presidential impeachment trials can been seen as conveying some expectations about the position. One was that a member of the federal judiciary would be an appropriate person to direct the trial of a President of the United States. Not only was presiding over trials a core function of the office of judge, the judicial branch of the newly created federal government was expected to be independent of the other branches.

Another expectation was that the Chief Justice, by virtue of his position, was the nation's primary legal authority. It was necessary, in a trial determining whether the nation's chief executive should remain in office, to have a person of nearly comparable status presiding. The Chief Justice was the personification of the Court's authority, more so than any of the Associate Justices. He was, as it were, the Court's commanding officer, whose status outranked that of his judicial colleagues.

The idea that collegial courts (ones composed of multiple judges who made decisions collectively) would have "presiding" or "chief" judges had long been established in England at the time of the American Revolution, and was very likely imported into American legal systems as a matter of course. Collegial courts required some member to be responsible for organizing their proceedings and facilitating their deliberations; a chief judge performed that role. With the assumption, in Anglo-American jurisprudence, that collegial courts would have presiding officers came the assumption that those officers would, by virtue of their organizational powers, hold a more senior status than their associates.

One can see evidence of the special seniority of the Chief Justice from America's earliest years. During the tenure of John Jay (17891795), the Court was composed of five or (after 1790) six Justices. It decided comparatively few cases, and in most of those cases the Justices delivered and published opinions "seriatim," or separately. The order in which the seriatim opinions were published (and apparently delivered) was strictly by reverse seniority, with the most junior Justice (James Iredell or William Paterson) delivering his opinion first and Chief Justice Jay delivering his last. In many instances Jay's opinion was followed by a brief paragraph, with the heading "By the Court," which announced the precise disposition of the case. Occasionally an opinion would only consist of this "By the Court" paragraph; there would be no accompanying opinions. In those instances, the Chief 
Justice would deliver the "By the Court" opinion. ${ }^{6}$ On one occasion, after Jay had resigned from the Court and had been temporarily succeeded by John Rutledge, ${ }^{7}$ Rutledge delivered a "By the Court" opinion in a case in which it was clear that he had not participated in the decision. $^{8}$

During the tenure of Oliver Ellsworth (1796-1800) the Justices issued seriatim opinions less frequently. By this point practices had developed which clearly conveyed the special seniority of the Chief Justice. On almost every occasion in which Ellsworth was present when an opinion of the Court was announced, he was recorded as having delivered that opinion. When Ellsworth was not present (which was comparatively often, because he was ill for some of his tenure and was absent for nearly a year on a diplomatic mission), or did not participate in the decision, the Court's reporter sometimes noted that in the Chief Justice's absence another Justice was delivering the Court's opinion. ${ }^{9}$ The assignment of that Justice seems to have been done on the basis of seniority.

In addition, seriatim opinions on the Ellsworth Court tended to occur only in cases in which Ellsworth had not been present for the

${ }^{6}$ E.g., Georgia v. Brailsford, 3 U.S. (3 Dall.) 1, 3 (1794); Glass v. The Sloop Betsey, 3 U.S. (3 Dall.) 6, 16 (1794).

${ }^{7}$ After Jay resigned from the Court in June 1795, Rutledge was given a recess appointment by President Washington that July. He presided over the Court for a brief Term in August 1795. Rutledge subsequently made public his opposition to the Jay Treaty with France, which was extremely controversial. The Senate then declined to confirm him to the chief justiceship in December 1795. David J. Danelski, Ideology as a Ground for the Rejection of the Bork Nomination, 84 Nw. U. L. REV. 900, 901-02 (1990). After offering the position to Patrick Henry, who declined, and to William Cushing, who chose to remain an Associate Justice, Washington appointed Oliver Ellsworth Chief Justice in March 1796. David M. Levitan, The Effect of the Appointment of a Supreme Court Justice, 28 U. TOL. L. REV. 37, 42 (1996).

${ }^{8}$ The Court's minutes for August 12, 1795, indicate that Rutledge did not arrive in Philadelphia (where the Court sat) until late on that date and thus was not present for the first five days of argument in Talbot v. Jansen, 3 U.S. (3 Dall.) 133 (1795), which were August 7, 8, 9, 11, and 12. Rutledge did participate in arguments on August 13, 14,18 , and 19. 1 THE DOCumentary History OF THE Supreme COURT OF THE UNITED StATES, 1789-1800, at 246-52 (Maeva Marcus \& James R. Perry eds., 1985); 6 id. at 695 (Maeva Marcus ed., 1998). The opinions in Talbot included one by Rutledge. 3 U.S. (3 Dall.) at 169 .

${ }^{9}$ See Fowler v. Lindsey, 3 U.S. (3 Dall.) 411, 412 (1799) (describing a land dispute between the states of New York and Connecticut, where the reporter explained that Ellsworth, a resident of Connecticut, had recused himself). For one of several examples in which Ellsworth was absent and no explanation was given, see Brown $v$. Van Braam, 3 U.S. (3 Dall.) 344, 356 (1797). 
deliberations. ${ }^{10}$ By the close of Ellsworth's tenure, the practice of substituting opinions of the Court for seriatim opinions was sufficiently established $^{11}$-and sufficiently associated with the Chief Justice-that when the Justices reverted to seriatim opinions in the 1800 case of Bas v. Tingy, for which Ellsworth was absent, Justice Samuel Chase commented on that fact. ${ }^{12}$

In the early Marshall Court, the practice of the Chief Justice delivering the opinion of the Court, even when he had not necessarily written that opinion, continued. In a survey of Marshall Court opinions from 1801 to 1810, Herbert Johnson found that in every instance from 1801 to 1805 for which an opinion of the Court was announced, the reporter indicated that the Chief Justice had delivered the opinion or that, if the Chief Justice had not been present, the opinion had been delivered by the most senior Associate Justice. After 1805, this practice was occasionally modified, but quite sparingly. ${ }^{13}$ Johnson's findings, and some additional evidence, led him to conclude that the Justice who delivered the opinion in this period of the Marshall Court was not necessarily the author of the opinion. ${ }^{14}$

${ }^{10}$ E.g., Cooper v. Telfair, 4 U.S. (4 Dall.) 14, 18 (1800). I have found only one case, Fenemore v. United States, 3 U.S. (3 Dall.) 357, 363-64 (1797), in which Justices delivered seriatim opinions when Ellsworth was present.

${ }^{11}$ E.g., Clarke v. Russel, 3 U.S. (3 Dall.) 415 (1799); Wilson v. Daniel, 3 U.S. (3 Dall.) 401 (1798); Wiscart v. Dauchy, 3 U.S. (3 Dall.) 321 (1796).

${ }^{12} 4$ U.S. (4 Dall.) 37, 43 (1800) (Chase, J.) ("The Judges agreeing unanimously in their opinion, I presumed that the sense of the Court would have been delivered by the president; and therefore, I have not prepared a formal argument on the occasion.").

Johnson found that in the years from 1806 through 1808 only one opinion per Term did not reflect the seniority principle; in the 1809 and 1810 Terms four opinions each Term did not reflect it. GEORGE LEE HASKInS \& HERBERT A. JOHNSON, FOUNDATIONS OF POWER: JOHN MARSHALL, 1801-15, pt. 2, at 386-87 (The Oliver Wendell Holmes Devise History of the Supreme Court of the United States, vol. 2, Paul A. Freund ed., 1981).

${ }^{14}$ For instance, when Chief Justice Marshall was absent from Court when the case of M'Ilvaine v. Coxe's Lessee, 6 U.S. (2 Cranch) 280 (1805), was delivered, Justice Cushing, the most senior Associate Justice, delivered the opinion. Johnson concluded that the quality of the opinion in M'llvaine was "well beyond [Cushing's] capacities at that time, and perhaps beyond his professional ability even at a younger age." HASKINS \& JOHNSON, supra note 13, at 384. In addition, Marshall wrote a statement a year later in M'Ferran v. Taylor E Massie that indicated that he "did not ... concur in the opinion which has been delivered," and that he had "been directed to deliver" it. 7 U.S. (3 Cranch) 270, 282 (1806). Marshall's statement in M'Ferran, Johnson surmised, indicated that "the Court as a group had arrived at its common judgment and [Marshall] was merely performing his duty as presiding officer in accordance with established custom and practice." HASKINS \& JOHNSON, supra note 13, at 385. 
Thus, from the earliest years of the Supreme Court, seniority played an important role in the Court's proceedings, and the Chief Justice, regardless of the length of his tenure, was treated as the most senior of the Justices. The order of reverse seniority in which seriatim opinions appeared, when coupled with the fact that cases in which the Justices issued separate opinions almost invariably concluded with a "By the Court" dispositional paragraph, suggests that seniority was treated as subtly increasing the weight of a seriatim opinion. The practice of having the Chief Justice deliver the Court's opinion in all cases where he was present, even though he may not have written the opinion, suggests that the office of Chief Justice was regarded as personifying the Court. Even in years when the regular issuance of seriatim opinions might have underscored a perception that the Chief Justice was merely one member of a collegial Court, the special seniority of the chief justiceship was evident. And when, in the later years of the Ellsworth Court ${ }^{15}$ and the Marshall Court, seriatim opinions receded and an "opinion of the Court" became the norm, the association of the Court's work with its Chief Justice became more pronounced.

\section{B. The Chief Justiceship, the "Opinion of the Court" Practice, and Silent Acquiescence}

Although the special seniority of the chief justiceship was well established by the time John Marshall became Chief Justice in 1801, it had largely been reflected in dimensions of the office that were more closely connected to Court protocol than to actual power. Although the Chief Justice technically presided over arguments before the Court and its deliberations of cases, there is no direct evidence that the Chief Justices prior to Marshall sought to use their managerial powers in accordance with any substantive agendas. The decline of seriatim opinions under Ellsworth may have been an effort on his part to exert more substantive influence, but no relevant data exist to test this hypothesis. The practice of having the Chief Justice's seriatim opinion appear just before the "By the Court" dispositional paragraph

\footnotetext{
${ }^{15}$ There is evidence that in the later years of his tenure Ellsworth was attempting to expand the "By the Court" dispositional paragraph into something resembling an "opinion of the Court." E.g., Sims' Lessee v. Irvine, 3 U.S. (3 Dall.) 425, 456 (1799); Clarke v. Russel, 3 U.S. (3 Dall.) 415, 424 (1799); Brown v. Barry, 3 U.S. (3 Dall.) 365, $366-67$ (1797). In these cases, the opinions were introduced by variations of the statement, "the opinion of the Court was delivered by the Chief Justice." My thanks to Natalie Wexler for calling these examples to my attention.
} 
may have subtly strengthened the effect of that opinion, and the Chief's habitual delivery of Court opinions, whether or not he had written them, may have served to identify the Chief more closely with the Court than other Justices. But those functions were largely ceremonial. Under Marshall, however, the relationship between separate opinions by Justices and the opinion of the Court was altered, and the result was a significant increase in the internal powers of the Chief Justice.

Five years into Marshall's tenure, a close observer of the Court would have noticed that tendencies which had appeared during Ellsworth's chief justiceship had evolved into established practices. The "By the Court" dispositional paragraphs, invariably unsigned but associated with the Chief Justice under Ellsworth, had now come to be identified as "opinions of the Court." They were no longer merely summary resolutions of the issues under dispute in a case; they were full-blown opinions. Moreover, the practice of having the Chief Justice deliver the opinion in every case when he was present had resulted in Marshall's name being identified with some quite lengthy "opinions of the Court." Finally, seriatim opinions had virtually disappeared; indeed any opinions by Justices other than the Justice associated with the "opinion of the Court" were rare.

Those developments partially concealed a major change in the Court's deliberations that Marshall, very likely with the support of Justice Bushrod Washington, had instituted. Although the protocol by which the senior Justice (typically the Chief, since Marshall missed very few Court sessions in the first decade of his tenure) delivered the "opinion of the Court" was a holdover from Ellsworth's chief justiceship, the elimination of seriatim opinions and the lengthening of the "By the Court" paragraphs into more extensive "opinions of the Court," were innovations. But the significance of these changes was enhanced by another change that only the closest observers of the Court might have noticed. "Opinions of the Court" rarely revealed whether they represented the views of all the Justices or only a bare majority. ${ }^{16}$ Indeed, in some instances the opinions were not unani-

\footnotetext{
${ }^{16}$ For some instances in which opinions did reveal the status of the opinion of the Court, see Green v. Biddle, 21 U.S. (8 Wheat.) 1, 94 (1823) ("The above is the opinion of a majority of the Court."); The Frances \& Eliza, 21 U.S. (8 Wheat.) 398, 406 (1823) ("It is the unanimous opinion of the Court ....").
} 
mous: Justices who had voted against the majority's disposition-the "dissenters"-had "silently acquiesced" in the Court's opinion. ${ }^{17}$

In addition, the "opinion of the Court," which had been written by one Justice, had not been circulated among the Justices prior to being published. Neither the other Justices who had voted for the majority disposition of a case nor those who had opposed that disposition would have had an opportunity to review a case after voting on its outcome. The only people who would have access to the opinions of the Court accompanying dispositions of cases were the author of those opinions and the Court's reporter. The legal justifications advanced in Marshall Court opinions were thus typically the product of only one Justice.

A feature of the Marshall Court, even after its docket became more crowded and the cases it decided more momentous, was the very short time interval between the completion of oral arguments and the handing down of opinions. In a number of celebrated cases the Court rendered opinions in five or fewer days following the completion of an oral argument. ${ }^{18}$ This statistic has astonished modern commentators on the Court's business. It becomes more readily explicable when one introduces some distinctive features of the Marshall Court's working life, such as its practice of allowing counsel unlimited time for their arguments; the fact that Justices infrequently interrupted counsel and often took extensive notes during the arguments; and the fact that Justices repaired, after the completion of a day of arguments, to a boardinghouse where they all resided and where, as Justice Joseph Story put it, they "moot[ed] every question as [they] proceed[ed]" with their social intercourse. ${ }^{19}$ Apparently, the Marshall Court Justices

\footnotetext{
${ }^{17}$ For evidence of the practice of silent acquiescence, see Mason v. Haile, 25 U.S. (12 Wheat.) 370, 379 (1827) (Washington, J., dissenting) ("It has never been my habit to deliver dissenting opinions where it has been my misfortune to differ from those which have been pronounced by a majority of this Court."); Bank of the United States v. Dandridge, 25 U.S. (12 Wheat.) 64, 90 (1827) (Marshall, C.J., dissenting) ("I should now, as is my custom, when I have the misfortune to differ from this Court, acquiesce silently in its opinion ...."); The Nereide, 13 U.S. (9 Cranch) 388, 455 (1815) (Story, J., dissenting) ("Had this been an ordinary case I should have contented myself with silence; but ... I have thought it not unfit to pronounce my own opinion . . ..”).

${ }^{18}$ See G. EdWARd White, The Marshall COURT AND Cultural Change, 1815-35, at 181 (The Oliver Wendell Holmes Devise History of the Supreme Court of the United States, vols. 3-4, Paul A. Freund \& Stanley N. Katz eds., 1988) ("Of sixty-six constitutional cases decided with full opinions between 1815 and 1835, the Marshall Court decided seventeen no more than five days after the conclusion of the argument.").

${ }^{19}$ Letter from Joseph Story to Samuel P.P. Fay (Feb. 24, 1812), in 1 LIFE AND LETTERS OF JOSEPH STORY 215, 215 (William W. Story ed., Boston, Charles C. Little \& James Brown 1851).
} 
did not regard themselves as precluded from discussing cases whose oral arguments were still in process, and those discussions may well have facilitated their eventual dispositions of the cases. Moreover, when the Court made public its dispositions of cases, having formally noted them in its docket book (now known as the Court's journal), the Justice who announced the Court's result (typically Marshall) was not expected to provide an extended justification for it. The United States Reports containing the Court's opinions were typically published several months after the Court adjourned its yearly Term, which during Marshall's tenure consisted only of six to eight weeks. ${ }^{20}$

Nonetheless, the text of several major Marshall Court opinions appeared in early nineteenth-century newspapers, ${ }^{21}$ and comparisons between the newspaper versions (which often occupied several pages) and the official versions suggest that few changes were introduced. Moreover, contemporary observers reported that on occasion, when the Court handed down a decision, Marshall would begin reading from what appeared to be the opinion accompanying it. ${ }^{22}$ In short, on many occasions when Marshall "delivered" the opinion of the Court, he had already written that opinion himself. In fact, because of the delays accompanying publication of the United States Reports, the amenability of some newspapers to publishing even lengthy opinions, and the interest on the part of Justices in having their decisions communicated as widely as possible, it seems likely that on many occasions Marshall, after having satisfied himself that he would be with the majority in the disposition of a case, assigned himself the opinion and proceeded to draft it while the Court's session in Washington was still going on.

Marshall could do this with impunity, if the practices he had introduced to the Court remained established, because he could expect that there would be no need for him to circulate a draft opinion to his colleagues and that there would be no published dissents from those

${ }^{20}$ See CARL B. Swisher, The TANey Period, 1836-64, at 293-318 (The Oliver Wendell Holmes Devise History of the Supreme Court of the United States, vol. 5, Paul A. Freund ed., 1974) (summarizing the job descriptions, including publication of opinions, of the Court clerk and Court reporter); WHITE, supra note 18, at 183, 384-92 (describing the duties of the Court reporter and the tenures of Court Reporters Henry Wheaton and Richard Peters).

${ }^{21}$ See WHITE, supra note 18, at 928 (explaining that a few newspapers and journals "treated periodic reports on the official business of governmental institutions as part of their function," and thus reported the Court's opinions).

${ }^{22}$ See, e.g., Letter from Daniel Webster to Jeremiah Mason (Feb. 4, 1819), in 16 The Writings AND SPEEches OF DANIEL WEBSTER 43, 43 (1903) (describing Marshall's deliverance of the opinion in Trustees of Dartmouth College v. Woodward, 17 U.S. (4 Wheat.) 518 (1819)). 
Justices who had silently acquiesced in a case's disposition. The content of an opinion was a matter only for himself and the Court's reporter. Thus it seems fair to surmise that, on many occasions, the day on which the Marshall Court "handed down" a decision was the day on which John Marshall had completed a draft opinion in that case.

In 1822, Thomas Jefferson wrote a letter to William Johnson, whom he had appointed to the Court in 1805, complaining, among other things, about the practice of silent acquiescence on the Court. Under the practice, Jefferson maintained, "nobody" in the outside public "knows what opinion any individual member gave in any case, nor even that he who delivers the opinion, concurred in it himself." 23 Johnson wrote back that when he had first come on the Court he found that Marshall had been "delivering all the opinions in cases in which he sat, even in some instances when contrary to his own judgment and vote. ... [When I protested against this], the answer was [that] he is willing to take the trouble and [that the practice] is a mark of respect to him." ${ }^{24}$ Johnson then said that eventually he had persuaded his colleagues "to adopt the course they now pursue, which is to appoint someone to deliver the opinion of the majority, but leave it to the discretion of the rest of the judges to record their opinions or not ad libitum. ${ }^{25}$

The letter confirms that the seniority protocol was controlling the delivery of Court opinions in the early years of Marshall's tenure, and that it served on occasion to conceal the actual authorship of the opinions. The letter also indicates that once the protocol of having the Chief Justice deliver the opinions in all cases was relaxed, there was no comparable protocol for the assignment of opinions, assuming that the Justice who "deliver[ed] the opinion of the majority" actually wrote that opinion. ${ }^{26}$ The change Johnson helped institute only gave Justices who differed from the majority "the discretion ... to record

${ }^{23}$ Letter from Thomas Jefferson to William Johnson (Oct. 27, 1822) [hereinafter Jefferson Letter], in 10 THE WRITINGS OF THOMAS JEFFERSON, 1816-1826, at 222, 225 (Paul Leicester Ford ed., New York, G.P. Putnam's Sons 1899).

${ }^{24}$ Letter from William Johnson to Thomas Jefferson (Dec. 10, 1822) [hereinafter Johnson Letter], quoted in DONALD G. MORGAN, JUSTICE WILliam JOHNSON: THE FiRST DisSENTER: THE CAREER AND CONSTITUTIONAL PHILOSOPHY OF A JEFFERSONIAN JUdGE 181-82 (1954). The handwritten letter is in the Jefferson Collection at the Library of Congress, available at http://memory.loc.gov/cgi-bin/query/P?mti:6:./temp/ ammem_ax5p::. Morgan was the first of several scholars to make extensive use of this exchange between Jefferson and Johnson.

${ }_{26}^{25}$ Johnson Letter, supra note 24.

${ }^{26}$ Id. 
their opinions or not." ${ }^{27}$ When one examines the frequency of concurring and dissenting opinions on the Marshall Court in light of Johnson's letter, it appears that few Justices took the opportunity to depart from the practice of silent acquiescence by making their opposition public.

Johnson's letter to Jefferson also provides an explanation for the practice itself. "Some case soon occurred" after his appointment, Johnson wrote,

in which I differed from my brethren, and I thought it a thing of course to deliver my opinion. But, during the rest of the session I heard nothing but lectures on the indecency of judges cutting at each other, and the loss of reputation which the Virginia appellate court had sustained by pursuing such a course. At length I found that I must either submit to circumstances or become such a cypher in our consultations as to effect no good at all. I therefore bent to the current, and persevered until I got them to adopt [my proposed change]. ${ }^{28}$

The Justices on the Court at the time Johnson joined it were, in order of seniority, Marshall, William Cushing, Samuel Chase, William Paterson, and Bushrod Washington. Of those, only Marshall and Washington, both of whom had practiced in Virginia, would have been intimately familiar with "the Virginia appellate court," so it seems likely that they were the source of the "lectures." But the practice that Johnson confronted did not only consist of an opinion of the Court with no concurrences or dissents; it involved Marshall's delivering all the Court's opinions, even when they were "contrary to his own judgment and vote." And although Johnson reported that this practice was explained as a gesture of respect to Marshall, he soon "found out," he told Jefferson, "the real cause." ${ }^{29}$

The "real cause" of silent acquiescence, Johnson believed, was that it served to shield Justices who were unwilling or incapable of writing opinions on a regular basis. Jefferson had suggested that " $[\mathrm{t}]$ he practice is certainly convenient for the lazy, the modest \& the incompetent," for it "saves them the trouble of developing their opinion methodically and even of making up an opinion at all." ${ }^{, 0}$ Johnson

${ }^{27}$ Id.

${ }^{28} \mathrm{Id}$.

${ }^{29} \mathrm{Id}$.

${ }^{30}$ Jefferson Letter, supra note 23, at 225. Jefferson had previously expressed this view of the silent acquiescence practice to others. For instance, in 1820, he wrote fellow Court critic Thomas Ritchie that "[a]n opinion is huddled up in conclave, perhaps by a majority of one, delivered as if unanimous, and with the silent acquiescence of lazy or timid associates, by a crafty chief judge, who sophisticates the law to his mind, by the 
pointedly confirmed this. He discovered on coming to the Court in 1805 that "Cushing was incompetent," that "Chase could not be got to think or write," that Paterson "was a slow man and willingly declined the trouble," and that "the other two judges you know are commonly estimated as one judge."

Although Johnson indicated that by 1822 the protocol of Marshall's delivering the opinions in all cases had been abandoned, the number of concurring and dissenting opinions remained very low. Beginning in the 1823 Term, however, Johnson began to write separate opinions, particularly in constitutional cases. In an 1824 opinion he announced that "in questions of great importance and great delicacy, I feel my duty to the public best discharged, by an effort to maintain my opinions in my own way," ${ }^{32}$ and between that year and 1833, when he left the Court, he produced nine concurring and eighteen dissenting opinions. ${ }^{33}$ Most of Johnson's associates declined to join him in that practice: Marshall, Washington, Thomas Todd, Gabriel Duvall, Joseph Story, and Smith Thompson produced a grand total of ten dissents and no concurrences between 1824 and $1833 .{ }^{34}$ Some of the newer appointees in the later years of Johnson's tenure, however, wrote separately more often, particular Henry Baldwin and John McLean, who published fifteen dissents and two concurrences between them from 1830 through $1833{ }^{35}$

The "opinion of the Court" and silent acquiescence practices underscored the special seniority of the Chief Justice. His opportunity to deliver the Court's opinions had been a function of seniority; the opportunity to change the Court's opinion-writing customs from seriatim opinions to an opinion of the Court can also be seen as related to the prerogatives of his office. Even Chiefs operating at times in which seriatim opinions had been the norm had garnered some slight advantages from the order in which those opinions were published, and Ellsworth had apparently converted these advantages into a process that deemphasized seriatim opinions and emphasized the "By the Court" paragraphs, which he typically delivered.

turn of his own reasoning." Letter from Thomas Jefferson to Thomas Ritchie (Dec. 25, 1820), in 10 THE WRITINGS OF THOMAS JEFFERSON, supra note 23, at 169, 171.

${ }^{31}$ Johnson Letter, supra note 24.

${ }^{32}$ Gibbons v. Ogden, 22 U.S. (9 Wheat.) 1, 223 (1824) (Johnson, J., concurring).

33 See MORGAN, supra note 24, app. II at 306-07 (tabulating the opinions of each Justice during this time period).

${ }^{34} I d$.

${ }^{35} I d$. 
So Marshall had profited from the special seniority of his predecessor Chiefs. But he had gone much further. He had, in effect, garnered for himself the opportunity to write every opinion for the Court in which he was in the majority, and to ensure that dissenters from that opinion would keep silent. He was the first Chief Justice decisively to convert protocol seniority into internal power.

\section{The Assignment Power of the Chief Justice: Early Practice}

It may be assumed that part of the reason Marshall was able to write, as well as to deliver, so many opinions in the early years of his tenure was that the current assignment power of the Chief Justice was in place. That assumption cannot be confirmed. The current assignment power of the Chief Justice exists in a context in which cases set for disposition by the Court's conference are discussed in a regular order, based on seniority, and in which the Chief Justice is expected to assign opinions when he is with the majority and the most senior associate Justice with the majority to assume that role when the Chief opposes the majority's disposition. Moreover, the assignment of opinions has for some time been handled in accordance with a principle of roughly equal distribution of opinions among the Justices.

There is no indication that this procedure was followed on the Marshall Court. As noted, no formal conference took place among the Marshall Court Justices; they simply "mooted" cases as they "proceeded" to discuss them informally in the boardinghouse while the cases were being argued. There is no evidence that those discussions were conducted according to any formal procedure, although Marshall was surely the nominal chair of them. And there is nothing to suggest that Marshall made an effort, once votes on cases had been taken, to assign opinions on an equal basis. To the contrary, there is substantial evidence that Marshall took on most of the opinions himself. In a thirty-four-year tenure Marshall wrote 547 opinions. Duvall was on the Court for twenty-three of those years; he produced fifteen opinions. Todd, who overlapped with Marshall for eighteen years, produced fourteen. ${ }^{36}$ In the years between 1816 and 1823 , when the Court issued a very high percentage of opinions without any recorded

${ }^{36}$ WhITE, supra note 18, at 191 (using the notations in volumes 1 Cranch through 9 Pet. (5 to 34 U.S.)); see also Robert G. Seddig, John Marshall and the Origins of Supreme Court Leadership, 36 U. PITT. L. REV. 785, 800 tbl.1 (1975) (comparing Marshall's numbers to all other Justices during his tenure). 
concurrences or dissents, ${ }^{37}$ Marshall wrote for the Court 124 times, Story 66 times, Johnson 47 times, and all the other Justices combined only 65 times.

Although Chief Justice Roger Taney was apparently less inclined than Marshall to write a large percentage of the Court's opinions, ${ }^{39}$ there is no authoritative evidence that during Taney's tenure the Court's current assignment practice had come into being. ${ }^{40}$ What evidence there is suggests a more informal process. The Dred Scott case $^{41}$ may have been atypical, but there the Justices apparently canvassed informally on its issues, then came to an initial disposition, supported by five Justices, that Dred Scott was a citizen of the United States, and thus eligible to bring suit in federal court, but was at the same time a slave under Missouri law. ${ }^{42}$ The opinion in the case was assigned to Justice Samuel Nelson, a member of the majority, with Taney and Jus-

${ }^{37}$ In the 302 opinions rendered by the Court in this period, there were only twenty-four dissents and eight concurrences. WHITE, supra note 18, at 184 (using the notations in volumes 1 through 8 Wheat. (14 to 21 U.S.)).

${ }^{38} \mathrm{Id}$.

${ }^{39}$ In commemorative remarks after Taney's death in 1864, former Justice Benjamin R. Curtis said that Taney was "aware that many of his associates were ambitious of [writing opinions]," and that "these considerations often influenced him to request others to prepare opinions which he could and otherwise would have written." Benjamin Robbins Curtis, Character and Public Services of Chief Justice Taney, Remarks Made at a Meeting of the Boston Bar (Oct. 15, 1864), in 2 A MEMOIR OF BENJAMIN RoBBINS CURTIS 336, 341 (Benjamin R. Curtis ed., Boston, Little, Brown, \& Co. 1879). A study of Chief Justices' "self-assignment" of majority opinions in "salient" cases found that Marshall had the power to assign nineteen of twenty-one salient cases, and gave seventeen to himself, while Taney was only able to assign twelve of eighteen such cases, and gave only five to himself. Saul Brenner, The Chief Justices' Self Assignment of Majority Opinions in Salient Cases, 30 Soc. SCI. J. 143, 146 (1993). By "salient cases," Brenner meant decisions, mainly but not exclusively involving constitutional law issues, that Supreme Court scholars have subsequently considered important. Id. at 145.

${ }^{40}$ Charles Fairman states that during the Chase Court " $[\mathrm{t}]$ he writing of opinions was assigned by the Chief Justice-save that if he were dissenting, the senior Justice in the majority would select the one to write." CHARLES FAIRMAN, RECONSTRUCTION AND REUNION, 1864-88, PART ONE, at 66 (The Oliver Wendell Holmes Devise History of the Supreme Court of the United States, vol. 6, Paul A. Freund ed., 1971) [hereinafter FAIRMAN, PART ONE]. Fairman points to Chase's diary entry for support: "Field intimated that Miller was displeased with my assignment of cases . . ." Id. at 66 n.129 (citing Salmon P. Chase, Diary Entry (Jan. 7, 1866) [hereinafter Chase Diary Entry]).

Although Fairman states that the assignment practice had been in place for many years, his evidence does not necessarily indicate that it was in place on the Chase Court. Chase's diary only indicates that he was assigning cases, not that he was doing so only when he voted with the majority.

${ }^{41}$ Dred Scott v. Sandford, 60 U.S. (19 How.) 393 (1857).

${ }^{42}$ SWISHER, supra note 20, at 615-19. 
tices James Wayne, Peter Daniel, and Benjamin Curtis insisting that the question of Scott's citizenship needed first to be decided. ${ }^{43}$

Had current assignment practice been followed, the assignment of the opinion to Nelson would have been made by Justice John McLean, the senior Justice in the majority. ${ }^{44}$ But McLean was one of two Justices who subsequently declared his intention of going beyond Nelson's opinion to reach issues such as the citizenship of blacks and the constitutionality of the Missouri Compromise. ${ }^{45}$ It seems odd that McLean would have assigned the opinion to Nelson, who persisted in his narrow disposition of the case, if he believed that the Court should take up issues that Nelson's opinion avoided. ${ }^{46}$ The Court's subsequent decision to abandon Nelson's opinion, and to address those issues, was precipitated by a motion made by Wayne. At that point the Justices apparently recanvassed their views, ${ }^{47}$ resulting in seven Justices concluding that Scott lost the case either because he was not a citizen of the United States or because he could not have become free on entering Illinois Territory, since the Missouri Compromise, under which the federal government outlawed slavery in some federal territories, was unconstitutional. ${ }^{48}$

After that recanvass, all the Justices resolved to file opinions, and Taney's opinion was identified as the opinion of the Court. ${ }^{49}$ Since Taney was now with the majority in its disposition of the case, he might have assigned the opinion of the Court to himself, but the fact that all Justices were expected to write separately suggested that Taney's "opinion" might not eventually command a majority in its reasoning. In the end, only Wayne's opinion explicitly supported Taney's. Grier concurred with Taney only in finding the Missouri Compromise unconstitutional; Daniel, Campbell, and Catron also agreed in that result, but for separate reasons; Nelson's opinion con-

Id. at 619 .

44 The Dred Scott case was handed down in 1857. McLean was appointed to the Court in 1830. The other members of the majority were Justices John Catron, appointed in 1837; Nelson, appointed in 1845; Robert Grier, appointed in 1846; and John Campbell, appointed in 1853.

${ }^{45}$ SWISHER, supra note 20, at 617. Justice Catron, in a letter to President-elect James Buchanan, did not identify the two Justices, but Swisher states that they were "probably known to Buchanan as McLean and Curtis." Id. (citing Letter from John Catron to James Buchanan (Feb. 19, 1857)).

${ }^{46}$ Nelson's published opinion in the Dred Scott case was identical to the one he had written as the "opinion of the Court" prior to its being abandoned. Id. at 625-26.

Id. at 619

${ }^{48}$ For a summary of the opinions, see $i d$. at 622-29.

${ }^{49} I d$. at 619 . 
tinued to maintain his narrow view of the case; and McLean and Curtis dissented, disagreeing with Taney on both the status of Scott's citizenship and the constitutionality of the Missouri Compromise. After the opinions appeared, it was hard to know what the the collective basis of the Dred Scott opinion was. ${ }^{50}$

The Dred Scott case, in its aftermath, also illustrated that the practice of one Justice preparing an opinion of the Court, not circulating it before delivery, and then dispatching it to the Court's reporter for eventual publication, was still extant in the late years of Taney's tenure. In 1841, Taney wrote a letter to Court Reporter Richard Peters in which he said that "[a] fashion has lately grown up, to examine after Term, opinions delivered in court, and to write answers to them to be published in the reports." ${ }^{51}$ Taney disapproved of the practice, although he admitted that once an opinion had been filed with the clerk (an 1835 rule of the Court had made such filing mandatory, but only for opinions of the Court ${ }^{52}$ ), any Justice was entitled to a copy. ${ }^{53}$ He told Peters that he did not intend to make his separate opinions generally available, and that he would hold them until the very last minute before giving them to Peters for immediate publication. ${ }^{54}$ The letter confirms that on the Taney Court not only were opinions not circulated prior to their being delivered, they were not circulated at all in most instances. There also seems to have been an expectation that once an opinion of the Court was read by its author in conference or in Court, significant changes would not be made to it before publication. ${ }^{55}$

\footnotetext{
${ }^{50}$ Two contemporary reviews of the Dred Scott decision, one in the North American Review and the other in the Law Reporter, emphasized the differences among the majority Justices and suggested that the Taney opinion could not fairly be characterized as an "opinion of the Court." Timothy Farrar, The Dred Scott Case, 85 N. AM. REV. 392 (1857); Horace Gray \& John Lowell, The Case of Dred Scott, 20 LAW REP. 61 (1857). Both reviews are cited, and their authors identified (the reviews were both anonymous), in SWISHER, supra note 20, at 642-43.

${ }^{51}$ Letter from Roger B. Taney to Richard Peters (Mar. 22, 1841), quoted in SWISHER, supra note 20, at 302.

${ }^{52}$ The Court's rule stated: "All opinions delivered by the court shall immediately, upon the delivery thereof, be delivered over to the clerk to be recorded." FAIRMAN, PART ONE, supra note 40, at 70 (quoting Supreme Court Rule 25). An opinion was "delivered by the court" " $[\mathrm{w}]$ hen a justice had read the opinion, in full or in summary, from the bench." Id.

${ }^{53}$ SWISHER, supra note 20, at 302.

${ }^{54} I d$.

${ }^{55}$ Cf. The Passenger Cases, 48 U.S. (7 How.) 283, 515-16 (1849) (Daniels, J., dissenting) (deploring the significant changes made to the opinion of the Court after it had "been propounded from the bench").
} 
Taney seems to have assumed that this would be the practice with Dred Scott, and he was highly offended when Curtis published his dissenting opinion in that case in a Boston newspaper shortly after the decision was handed down. ${ }^{56}$ In his opinion Curtis had included evidence from the framing period that suggested that several states had treated persons of African descent as citizens. ${ }^{57}$ In response to that evidence, Taney intended to revise his Dred Scott opinion and did not release it to the Court reporter. ${ }^{58}$ When Curtis learned that Taney was revising his opinion, he wrote the clerk of the Court asking that his opinion not be printed and for a copy of Taney's. ${ }^{59}$ The clerk responded that Taney had issued a written order on April 6, a month after the Justices had delivered their Dred Scott opinions, that no one should be given access to his opinion. ${ }^{60}$

Curtis found it hard to believe that Taney's order applied to a member of the Court, so he wrote the clerk again, and when informed that it did, wrote Taney. ${ }^{61}$ This began a correspondence, from April to June 1857, in which Taney intimated that Curtis, who had allowed his opinion to be published in a newspaper, wanted Taney's opinion for political purposes, and Curtis cited the rule requiring that opinions of the Court be filed with the clerk. ${ }^{62}$ The incident contributed to Curtis's decision to resign from the Court that September. ${ }^{63}$ It indicates that on the Taney Court, at least, there was still a strong embargo against public disputes among Justices in the form of exchanges in opinions. Even though Taney was well aware that Dred Scott was an exceptional case in the number of opinions it stimulated and the differences among the Justices revealed in these opinions, he insisted that the tradition of the Court not to circulate opinions once they had been delivered, and not to revise them significantly after colleagues had had an opportunity to hear them, should be maintained. He felt that Curtis had breached that protocol by releasing his opinion to a

\footnotetext{
${ }^{56}$ See SWISHER, supra note 20, at 632-33 (describing the exchange between Taney and Curtis following the publication of Curtis's dissent).

${ }^{57} I d$.

${ }^{58} I d$. at $632-33$

${ }^{59} I d$. at 633 (citing Letter from Benjamin R. Curtis to William T. Carroll (Mar. 14, 1857)).

${ }^{60} I d$.

${ }^{61}$ Id. at 634 .

${ }^{62} I d$. The correspondence is set forth in 1 Curtis, supra note 39, at 211-30.

${ }^{63}$ See SWISHER, supra note 20, at 636-37 (explaining how Curtis's strained relationship with Taney, and the public's association of Curtis with the abolitionist cause that resulted from his opinion in Dred Scott, contributed to his decision to resign).
} 
newspaper and then making efforts to revise that opinion-and refute some of Taney's revisions-before official publication.

The Dred Scott evidence about the circulation and revision of opinions does not, of course, say anything directly about the process by which the Taney Court reached decisions or assigned opinions. But it suggests that the informal norms of the Marshall Court were still very much in place. Justices were not expected to snipe at one another in public by writing concurring and dissenting opinions directed at the language of opinions of the Court. The norm of silent acquiescence had been a technique by which Justices suppressed their differences, conveying the impression that the Court was a unified body. An understood corollary to silent acquiescence was that once a Justice produced an opinion of the Court, and read it to his colleagues, they would not fuss publicly about its language. This corollary meant that being assigned an opinion was not as onerous a task as it would have been in a Court whose norms required the circulation of, and formal acquiescence in, draft opinions. It meant that in most cases a Justice was only responsible for his vote.

So one might infer, once the norms of noncirculation and silent acquiescence are assumed to remain in place, that if something like a regularized process of opinion assignments existed on the Taney Court, the Justices assigning opinions would be less inclined to feel a need to distribute assignments equally among their colleagues. This was because writing an "opinion of the Court," in a process in which others, having committed themselves to the results of that opinion, have no expectation of even seeing it, let alone signing on to its language, can hardly be said to be an excessively burdensome task. Indeed, a process in which the only responsibility of the opinion writer is to prepare a set of justifications for the Court's official reports would seem likely to sort out those Justices who liked writing opinions from those who did not. If one assumes that there would invariably be Justices in the latter category, the process on the Taney Court, like that on the Marshall Court, would actually seem to precipitate the unequal distribution of opinions. An assigning Chief, or an assigning Justice or group of Justices, would be inclined to give "opinions of the Court" to those who liked writing them. Others could concentrate simply on making decisions.

Before extending this survey of the Court's internal deliberative practices further into the nineteenth century, it is worth pausing to consider a question that those practices inevitably raise for modern commentators. The combination of the norm of silent acquiescence 
and the absence of circulation of "opinions of the Court" prior to their appearing in the United States Reports caused the jurisprudential status of those opinions, when considered from modern perspectives, often to be misleading. Although a majority of Justices had typically endorsed the actual disposition of issues rendered by an "opinion of the Court," ${ }^{\prime \prime 4}$ only one had advanced the legal justifications for that disposition, and in most instances, at least through Taney's tenure, none of the other Justices had seen, let alone subscribed to, those justifications. The only persons who normally had access to an "opinion of the Court" as it evolved from draft status to official version in the United States Reports were the author of that opinion, the Court clerk, and the Court reporter. The clerk, after 1835, was given a copy of the opinion after the Court's disposition of a case was officially announced, but only for the purpose of keeping a record. The reporter, especially during Henry Wheaton's tenure ${ }^{65}$ was regularly involved in the editing of draft opinions before they were published, but the only Justice he consulted in the editing process was the author of the draft. $^{66}$

This meant that the reasoning of an opinion of the Court, so long as the practice of noncirculation of draft opinions remained in place, usually represented only the views of one Justice. In a jurisprudential climate in which the Court's majority opinions have come to be represented by their reasoning as much as by their results-the Court typically alludes to the reasoning of its precedents in following them, extending them, distinguishing them, or overruling them-learning that earlier opinions of the Court only represented the reasoning of one Justice may appear, to put it mildly, startling. But here again one needs to guard against the anachronistic projection of current attitudes onto the work of earlier Courts.

${ }^{64}$ Typically, but not invariably, as the Dred Scott case illustrates. Although Taney's opinion was designated the "opinion of the Court," a close reading of all the opinions in Dred Scott reveals that only Justice Wayne endorsed it in full, and that although a majority of Justices agreed that the petitioner Scott had lost his case, they did not agree on the reasons. SWISHER, supra note 20, at 625-28.

${ }^{65}$ Wheaton was the Court's reporter from the 1816 through the 1827 Terms. For illustrations of his editing of draft opinions of the Court, and how this influenced several cases' language and disposition, see WHITE, supra note 18, at 391-400.

${ }^{66}$ Wheaton and other reporters regularly consulted with the lawyers who had argued cases they reported, but this was for the purpose of assembling the summaries of arguments that were included in the Court's official reports, which were elaborately presented through Wheaton's tenure. Wheaton's successor, Richard Peters, reduced the argument summaries. WHITE, supra note 18, at 407-08. 
The nineteenth-century Court's practices of silent acquiescence and noncirculation took place in a different jurisprudential universe from that which came to develop in the early years of the twentieth century. A fundamental proposition of that universe was that judicial decisions were not the equivalent of positivistic enactments of law, such as the actions of legislatures, but rather mere evidence of legal principles. Those principles-whether manifested in provisions of the Constitution, prior common law decisions of courts, local customs and practices, conventions of "civilized" nations, the "laws" of nature, or foundational values of free republican governments-transcended judicial decisions and existed apart from them. "Law," in America, was understood as being composed of both the positivistic enactments of legislatures and members of the federal and state executive branches, and those transcendent, immanent principles. When a court made a decision, it was understood to be discerning legal principles and applying them to a dispute. Its decision was taken as evidence of the existence and applicability of the principles thought to govern the case it decided. ${ }^{67}$

A corollary to the above proposition is that judicial decisions could erroneously apply principles to cases. When a subsequent court, on reviewing such decisions as potential precedents, concluded that "demonstrable error" had occurred, no evidentiary weight was given to the decision. It was not simply thought of as "bad law" and overruled (although judicial overruling of "erroneous" precedents was not uncommon), but as "not law at all," as evidence about the content or meaning of "law" that turned out to be faulty.

This attitude toward the status of judicial decisions, so long as it persisted in American jurisprudence, produced what can be regarded, from a modern perspective, as a diminished status for judicial opinions as precedents. Since the content of a judicial opinion was not seen as the equivalent of law but only as evidence of law's application to a particular case, the practice of stare decisis was qualified: what-

${ }^{67}$ For evidence of a multiplicity of early nineteenth-century sources supporting the generalizations made in this paragraph, see WHITE, supra note 18, at 111-56 (ranking sources of law in early nineteenth-century jurisprudence and explaining attitudes toward them); Caleb Nelson, Stare Decisis and Demonstrably Erroneous Precedents, 87 VA. L. REV. 1, 4-5, 9-48 (2001) (describing arguments for decisions based on external sources of law and the belief that common law was derived from external sources). For a pioneering treatment of some of those sources, see Frederick G. Kempin, Jr., Precedent and Stare Decisis: The Critical Years, 1800 to 1850, 3 AM. J. LEGAL HIST. 28, 33-34 (1959) (arguing that some sources of law were thought of as external and superior to judicial decisions). 
ever presumption lay in favor of following established "case law" needed to be understood as capable of being overcome once that "case law" was determined to be demonstrably erroneous. This did not mean that a freewheeling attitude toward existing judicial decisions prevailed in nineteenth-century America. Like their twentiethand twenty-first-century counterparts, judges and commentators struggled to reconcile the force of settled expectations with a recognition that prior decisions had come to be seen as deeply flawed in some fashion. ${ }^{68}$ It did mean, however, that the reasoning in a judicial opinion was understood simply as evidence of the applicability of a legal principle or principles to a case. It was a "gloss" on the law, not the law itself. One can see, in this context, how the stakes in opinion writing might have been perceived to have been lower, especially since the reasoning in an opinion of the Court would have been perceived as simply an effort to apply principles to cases rather than as a doctrinal roadmap for future cases. ${ }^{69}$

\section{Changes IN The Later Nineteenth CENTURY}

The jurisprudential climate that helped foster the practices of silent acquiescence and noncirculation does not appear to have been significantly modified for the balance of the nineteenth century, despite major changes in the volume of the Court's business and, eventually, in its internal protocols. As the Civil War drew to a close, and Salmon P. Chase replaced Taney as Chief Justice, the Court's docket dramatically increased, but some features of the Court's internal process remained constant, the most notable being the noncirculation of opinions. Even though the volume of Court business had sufficiently increased by Chase's tenure, such that cases would routinely not be argued for two or three years after being placed on the Court's docket, the actual deliberation and disposition of cases remained summary. Typically only a month elapsed between the time a case was

${ }^{68}$ Nelson, supra note 67 , at 9-48, has an extended discussion of techniques early nineteenth-century courts and commentators used in their efforts to reconcile settled expectations with perceptions that prior decisions now seemed "demonstrably erroneous." Among those techniques was one based on the now-obscure theory that successive judicial interpretations of legal principles, even if not necessarily "correct," could become "liquidated," which in the early nineteenth century meant "fixed or established." Id. at 10-22. Although even "liquidated" interpretations could be abandoned as "demonstrably erroneous," the idea of liquidation served to reinforce settled jurisprudential expectations. Id.

${ }^{69}$ I am indebted to Ted Ruger, who read an earlier draft of this Article, for his contributions to this last set of observations. 
argued and the time a decision was handed down. Cases were generally discussed, and voted on, in the Court's Saturday conference following the week in which they had been argued. Opinions were assigned after the voting, and the author of the "opinion of the Court" was expected to produce it in two or three weeks. A prepared opinion was expected to be read to the other Justices in a Saturday conference, and then delivered in Court the following Monday. It would then go to the clerk, and eventually to the reporter for publication. ${ }^{70}$

The increased number of cases brought to the Court-which resulted, from 1869 on, in the Justices' supplementing their regular "December Terms," which began in early December and lasted approximately seventeen weeks, with an October "adjourned Term," in which they took up to two months to complete work left over from the previous spring-had not resulted in a more extensive deliberation process. Indeed a summary deliberative process was the only way in which the Court could have kept abreast of its docket. Authors of opinions still did not circulate them, and concurrences and dissents remained rare. The historian Charles Fairman, after describing the absence of circulated opinions, suggested that "the other Justices would generally have no opportunity to read the opinion and to reflect upon the drafting," and that "[e]vidently there was not a very high sense of corporate responsibility."

\section{A. Agenda Setting}

The added workload on the Chase Court doubtless placed a heavier burden on its Chief Justice to set the agenda for conferences and to move cases through the docket. But Chase does not seem to have been particularly attentive to administrative details. This may have been a function of his initial lack of interest in the work. During his

\footnotetext{
${ }^{70}$ FAIRMAN, PART ONE, supra note 40, at 69-70. It is not clear when the practice began under which a Justice who had been assigned an "opinion of the Court" read that opinion (or perhaps portions of it) in conference. It may have been a result of the Justices' no longer living together in a boardinghouse: during Taney's tenure they began to occupy different houses in Washington, sometimes with their families. See SwISHER, supra note 20, at 8-9, 837-39 (contrasting the early years of the Taney Court, when all the Justices were expected to live in the boardinghouse, with its later years, when some Justices had bought permanent houses in the District of Columbia and others lived in rented houses or hotels). Swisher also notes that Justice Nelson, after initially being assigned the "opinion of the Court" in Dred Scott, read it to Justice Campbell in "his room," but "not... at conference." SWISHER, supra note 20, at 619 (citing Letter from John A. Campbell to George T. Curtis (Oct. 30, 1879)).

${ }^{71}$ FAIRMAN, PART ONE, supra note 40 , at 70.
} 
first Term, in January 1865, he wrote a friend of "the painful monotony of hearing, reading, thinking and writing on the same class of subjects and in the same way, all the time-morning, noon, evening and night," mentioning" in his time at the Court. ${ }^{73}$ At any rate, he misunderstood the terms of a conference discussion involving the Court's resumption of appeals from southern states, which had been suspended during the Civil War, and announced, in February 1866, that lawyers could not participate in those cases unless they had satisfied the "test oath" requirements of congressional statutes, passed during the war, which conditioned the practice of law on a showing of loyalty to the Union. ${ }^{74}$ On hearing Chase's announcement, Justice David Davis said that it was not what he had understood the Court to have decided, and the next day Chase announced that attorneys could appear without proof of having taken an oath. ${ }^{75}$ At the same time he dissented from that order. $^{76}$

The incident suggests that Chase was sometimes strikingly casual in his recollections of the Court's deliberations and also inclined to draw conclusions that suited his purposes. Another example comes from cases testing the constitutionality of the federal and state "test oaths" themselves, which the Court heard in March 1866. The Court, finding itself deeply divided on the cases, postponed a decision on them until its December 1866 Term. At the time of the postponement, it appeared that four Justices-James Wayne, Samuel Nelson, Robert Grier, and Nathan Clifford-were inclined to find the test oaths unconstitutional, and four others-Chase, Noah Swayne, Samuel Miller, and Davis-were inclined to sustain them, with Stephen Field's position being unclear (he would eventually find them unconstitutional). ${ }^{77}$

\footnotetext{
${ }^{72}$ Letter from Salmon P. Chase to "Dear friend" (Mar. 1865), quoted in JOHN Niven, SAlmon P. CHASE: A Biography 376 (1995).

${ }^{73}$ Salmon P. Chase, Diary Entry (Jan. 20, 1865), quoted in NIVEN, supra note 72, at 376.

${ }^{74}$ FAIRMAN, PART ONE, supra note 40, at 136-37.

75 Id. at 137 .

${ }^{76} 2$ The Diary OF ORVILle HickMan Browning 61-62 (James G. Randall ed., 1933). Browning, who frequently argued cases before the Court, was counsel in two appeals from southern states and was present to hear Chase's initial order, which was announced on February 13. Davis's reaction and Chase's modification of the order, along with his dissent, were issued the next day. FAIRMAN, PART ONE, supra note 40, at 136-37.

${ }^{77}$ The DiARY OF ORVILle HickMAN BROWNING, supra note 76, at 67, 69-70; Letter from Samuel F. Miller to William P. Ballinger (July 31, 1866), quoted in CHARLES FAIR-
} 
In May, two members of Congress-Representative John Hogan and Senator Reverdy Johnson-were quoted as saying that the Court had decided that the test oaths were unconstitutional but had postponed an opinion until its next Term. ${ }^{78}$ Johnson, who frequently argued before the Court, wrote a colleague that although the Court had decided the test oath cases, "the failure to announce the decision was ... mainly owing to the fact that the Judge selected to deliver the opinion had not time before the close of the term to prepare such a one as the importance and gravity of the question required"; the letter was published in the National Intelligencer on June $1 .^{79}$ On June 5, Justice Miller, having seen the letter, wrote Chase that Johnson's statement was false, and since the test oath was a major political issue in Missouri, perhaps someone from the Court should clarify the matter. ${ }^{80}$ Before the cases had been postponed, Justice Field had moved that the Court only decide the Missouri case and postpone the federal cases. This motion had been strenuously opposed by Miller, and eventually Grier moved that the Court postpone decision on all of the cases. Miller suggested to Chase that he saw "no wrong, but a manifest propriety in contradicting the assertion that the Court has decided an important case ... when it has done no such thing." ${ }^{81}$

Chase's reply indicated that he had "no memoranda of what took place" in the Court's conference on the test oath cases. ${ }^{82}$ Furthermore, he had no memory of the merits of Missouri cases being discussed at all, although he remembered an extensive discussion of the congressional test oath, Field's motion to separate the federal cases from the Missouri cases and decide the latter, Miller's "strong appeal" resisting that, and Grier's eventual motion to postpone all of the cases. $^{83}$ But Chase suggested there might have been a "caucus or conference" by some Justices "separate" from others, which he "kn[e]w

man, Mr. Justice Miller AND THE Supreme Court, 1862-1890, at 130-31 (1939) [hereinafter FAIRMAN, MR. JUSTICE MILLER].

${ }^{78}$ Hogan said in a speech in St. Louis on May 1, 1866, that "the Supreme Court has decided that the oath of Missouri is an unconsitutional oath," but that he did not know the information "from any written opinion which they have published." MO. REPUBLICAN, May 2, 1866, quoted in FAIRMAN, PART ONE, supra note 40, at 152.

${ }^{79}$ Johnson wrote the letter on May 30, 1866, to Hogan, who arranged for its publication in the National Intelligencer. FAIRMAN, PART ONE, supra note 40, at 152-53.

${ }^{80}$ Letter from Samuel F. Miller to Salmon P. Chase (June 5, 1866) [hereinafter Miller-Chase Letter], quoted in FAIRMAN, PART ONE, supra note 40, at 153-54.

${ }^{81} \mathrm{Id}$.

${ }^{82}$ Letter from Salmon P. Chase to Samuel F. Miller (June 9, 1866) [hereinafter Chase-Miller Letter I], quoted in FAIRMAN, PART ONE, supra note 40, at 154-56.

${ }^{83} I d$. 
nothing of." ${ }^{84}$ He would "be sorry to believe there was any such private arrangement or understanding., ${ }^{85}$

Chase's letter suggests that not only did he not keep records of what transpired in conference, he did not always recall what had taken place. Miller's "memory [was] so much more accurate than mine," he said, and he would be glad to get "an exact account of what did actually transpire." ${ }^{\prime 6}$ Indeed, Miller told Davis that Miller "sent Chase at [Chase's] request memoranda from my note book in which I have a full statement of the [Court's deliberations on the test oath cases] noted down at the time." ${ }^{87}$ Chase also encouraged Miller to make a public statement that the cases had not been decided. ${ }^{88}$

Miller, and Davis, did tell confidants that the cases had simply been postponed, and an article in a Missouri newspaper reported that fact on June 22, $1866 .{ }^{89}$ Around the same time, Justice Field, then in San Francisco, heard about Johnson's letter and sent a telegram to Chase asking whether the letter "required any notice from Judge[s]." On July 3, Chase wrote again to Miller, repeating that Johnson's letter was clearly inaccurate "unless there was, what I will not believe, a secret arrangement among five of the Judges that the CongressAttorney-oath cases should be postponed and that the Missouri oath case should be decided against the oath without any opportunity for prior consultation among the Judges." "If "If be true," Chase continued, "that a Judge was selected to prepare the opinion this also must have been agreed on in the caucus!" Chase wondered how Johnson "could . . have manufactured the story from whole cloth." ${ }^{93}$

Finally, Chase reported that after the Court had adjourned in early April 1866, Justice Clifford, accompanying Chase on a train to New York, had told him that after the Justices had agreed with Grier's

${ }^{84} I d$.

${ }^{85} I d$.

${ }^{86} \mathrm{Id}$.

${ }^{87}$ Letter from Samuel F. Miller to David Davis (June 28, 1866) [hereinafter MillerDavis Letter], quoted in FAIRMAN, PART ONE, supra note 40, at 157 n.95.

${ }^{88}$ Chase-Miller Letter I, supra note 82.

${ }^{89}$ MO. DEMOCRAT, June 22, 1866, reprinted in FAIRMAN, PART ONE, supra note 40, at 156; see also Miller-Davis Letter, supra note 87 ("I gave an emphatic contradiction [of the "falsehood" that the case had been decided], as you did . . ..").

${ }^{90}$ Telegram from Stephen J. Field to Salmon P. Chase (June 30, 1866), quoted in FAIRMAN, PART ONE, supra note 40, at 157.

${ }^{91}$ Letter from Salmon P. Chase to Samuel F. Miller (July 3, 1866) [hereinafter Chase-Miller Letter II], quoted in FAIRMAN, PART ONE, supra note 40, at 157.

${ }^{9}$ Id.

93 Id. 
motion in conference to postpone the test oath cases and were sitting in court for the last time before adjournment, Justice Nelson had said that Grier was now prepared to withdraw his motion so that the cases could be decided. ${ }^{94}$ Clifford told Chase that he had said to Nelson that he regarded the matter as settled and would not agree to reopening the cases. ${ }^{95}$ Chase had been unaware of any of this activity. ${ }^{96}$

The communications on the test oath cases reveal that, at least at that point in his career, Chase was hardly a master of the details of the Court's deliberations and had reason to believe that groups of Justices may have been caucusing on issues outside his presence. But it seems inconceivable that he could not even recall the Court's having discussed the Missouri test oath cases, especially since he had remembered Field's statement, which indicated that five Justices were prepared to find the Missouri test oath unconstitutional. The fact was that Chase, who supported test oaths, had an incentive to have the cases postponed, as did Miller: over the summer a Justice might change his mind or some of the more senior members of the Court (Nelson, Wayne, and Grier were each in their seventies) might retire or die.

Chase's doggedness, and his tendency to engage in sharp practice when he felt strongly about issues, was not limited to the test oaths episode. After the conclusion of considerable infighting among the Justices over the Legal Tender Cases, in which a newly expanded Court reversed a one-year-old decision of its predecessor in concluding that greenback notes could constitutionally be made legal tender for the payment of debts, ${ }^{97}$ Miller reported that Chase, who had written the Court's previous opinion finding a federal statute making greenbacks legal tender unconstitutional, "ha[d] resorted to all the strategems of the lowest political trickery to prevent [new legal tender cases] being heard, and the fight has been bitter in the conference room." "The excitement," Miller said, "has nearly used me up. It has been fearful; and my own position as leader in marshalling my forces, and keeping up their courage, against a domineering Chief, ... has been such a

\footnotetext{
${ }^{94}$ Chase-Miller Letter I, supra note 82.

${ }^{95} I d$.

${ }^{96} I d$.

${ }^{97} 110$ U.S. 421,450 (1883).

${ }^{98}$ Letter from Samuel F. Miller to William P. Ballinger (Apr. 21, 1870), quoted in FAIRMAN, MR. JUSTICE MILLER, supra note 77, at 170-71.
} 
strain on my brain and nervous system as I never wish to encounter again." ${ }^{99}$

The above evidence about Chase not only reveals the sort of Chief Justice he was, it indicates that by the time of the Chase Court there was still no formal protocol for the Court's deliberations. As Chase's diary entry indicates, many cases came to the Court on routine matters, and were disposed of in conference shortly after being argued. Others, however, such as the test oath cases or the legal tender cases, could, especially where the Justices were divided, occupy the Court for several weeks. Chase undoubtedly had autocratic tendencies, and was not loath to resort to "strategems" in the pursuit of outcomes he desired, but there is no evidence that he dominated his Court to the extent that Marshall, or even Taney, had. Miller reported, after Chase's death:

He liked to have his own way: but when he came upon the bench it was admirable to see how quietly and courteously the Court resisted his imperious will, never coming to direct conflict, and he finally had to take the position which he held, that he was the Moderator and presiding officer over the Supreme Court, and not possessed of any more authority than the rest of the Bench chose to give him. ${ }^{100}$

Chase himself had conveyed that view of his office in 1868, but the view was not entirely accurate. By the end of Chase's tenure in 1873, the Court was still sufficiently informal in its deliberative processes that a Chief Justice who commanded the intellectual and personal respect of his colleagues had opportunities to exert influence that exceeded those of his colleagues. But although Chase had some intellectual abilities and strong political principles, he never succeeded in disabusing his fellow Justices of the perception that he was a strongwilled, sometimes disingenuous partisan. A more tactful, less strategic, and more conscientious Chief would have been able to dominate his Court.

\section{B. Assigning Opinions}

Very little evidence has surfaced from the period of Chase's chief justiceship about the Court's practices in the assignment of opinions. Among Chase's colleagues were some Justices of great ability, such as Miller, Field, and Bradley, and Chase did not write the majority of his

99 Id.

${ }^{100}$ Newspaper Account of Interview with Samuel F. Miller (1878), quoted in FAIRMAN, PART ONE, supra note 40, at 26-27. 
Court's most significant opinions. ${ }^{101}$ Chase's comments to Miller about the test oath cases suggest that he took for granted that if a majority of Justices existed for the disposition of a case that he did not support, the opinion in that case would be assigned by that majority (he speculated to Miller that the selection of a Justice to prepare the opinion had been "agreed on in the caucus"). ${ }^{102}$ Chase's letter does not identify Wayne, the senior Justice in that majority, as having made the assignment; it suggests that the assignment was a collective decision. ${ }^{103}$

On the other hand, Chase's diary entry of January 7, 1866, makes it clear that he was assigning at least some cases. ${ }^{104}$ When that entry is taken together with Chase's letter to Miller about the test oath cases, it suggests that Chase took on assignments when he was with the majority, but when he was not, the process may have been more informal. In the sequence of cases testing the constitutionality of the Legal Tender Act of 1862, Chase assigned the first opinion to himself, but the second opinion was delivered and written by Justice William Strong, who had just been appointed to the Court. The most senior Justice in Strong's majority was Samuel Miller, a strong supporter of the legal tender legislation, but there is no evidence that Miller assigned the opinion to Strong.

Although the succession of Morrison Waite to the chief justiceship in 1874 (Chase died on May 7, 1873) produced a change in the attitude of the Chief Justice toward assignments, it did not apparently produce an alteration in the Court's assignment protocol. The Chief Justice continued to assign all cases in which he was with the majority, but when the Chief dissented, the assignment was made, as it had been on the Chase Court, by a caucus of the majority Justices. ${ }^{105}$

101 If one treats Brenner's definition of "salient" cases as the equivalent of "significant" ones, Chase was with the majority in nine of fourteen such cases during his tenure. He wrote the opinion of the Court in five such cases. Brenner associates "salient" cases with those listed as "major decisions of the Supreme Court" in CONGRESSIONAL QUARTERly, InC., The Supreme COURT AT WORK 211-55 (1990). He assumes that when Chief Justices wrote opinions for the Court they had assigned those opinions to themselves. Although this may well have been the case for the Marshall, Taney, and Chase Courts, there is no direct evidence confirming the practice. See Brenner, supra note 39 , at $145-46$.

${ }^{102}$ Chase-Miller Letter II, supra note 91.

${ }^{103} I d$.

${ }^{104}$ Chase Diary Entry, supra note 40.

${ }^{105}$ For an example, see Chief Justice Waite's Docket Book from United States v. Lee, 106 U.S. 196 (1882), in which Waite dissented and noted that the "opinion of the Court" had been given to Justice Miller "by assignment of his associates." CHARLES 
In contrast to Chase, Waite was highly interested in being counted with the majority in cases he regarded as significant, ${ }^{106}$ and he also seems to have assigned cases with a view toward making as equal a distribution of assignments as possible, taking into account the varying skills of his colleagues. ${ }^{107}$ The result was that during Waite's tenure the assignment power of the Chief became one of the devices by which the occupant of that position attempted to increase his internal stature.

Waite had had a somewhat embarrassing appointment to the chief justiceship. He was not President Grant's first choice; Grant's initial selection was Senator Roscoe Conkling of New York, a flamboyant figure who was one of the architects of the "spoils system" of patronage to which both major parties subscribed in the years following the Civil War. $^{108}$ After Conkling declined, three sitting Justices-Swayne, Miller, and Bradley-campaigned for the position, but Grant decided not to appoint someone from the Court. He then made a fruitless, almost comic, series of offers and appointments, offering the chief justiceship to two Senators; his Secretary of State, Hamilton Fish; his Attorney General, George Williams; and seventy-four-year-old Caleb Cushing, a political confederate. The Senators and Fish turned him down; Williams's name was withdrawn after evidence surfaced that he had mingled his personal accounts with those of the Justice Department; and Cushing withdrew his name after it became clear that the Senate would not confirm him. A process that had begun over the

FAIRMAN, ReCONSTRUCTION AND REUniOn, 1864-88, PART TwO, at 711 (The Oliver Wendell Holmes Devise History of the Supreme Court of the United States, vol. 7, Paul A. Freund \& Stanley N. Katz eds., 1987) [hereinafter FAIRMAN, PART TwO].

${ }^{106}$ In 1881, the historian George Bancroft asked Waite to list the most prominent cases involving constitutional questions that had been decided in his tenure. Waite mentioned seventy-two cases. In sixty-six of those cases he had voted with the majority. Letter from Morrison R. Waite to George Bancroft (May 23, 1881), quoted in C. PETER MAgRATH, Morrison R. WAITE: THE TRIUMPH OF CHARACTER 263 \& n.40 (1963).

${ }^{107}$ In a letter to Field, who had expressed annoyance at David Davis's having been given the opinion in United States v. Union Pacific Railroad Co., 91 U.S. 72 (1875), Waite said:

As for opinions in important cases, I don't know, but I think you fared better than the Judge who has the [Union Pacific] case did at the last term. Certainly during the present term he has had no advantage over you. I certainly intend to treat all my brethren fairly in this most delicate and at the same time important part of my work.

Letter from Morrison R. Waite to Stephen J. Field (Nov. 10, 1875), quoted in MAGRATH, supra note 106, at 259-60.

${ }^{108}$ For accounts of Waite's appointment, see MAGRATH, supra note 106, at 2-22; FAIRMAN, PART TWO, supra note 105, at 5-83. 
summer of 1873 had yielded no results by January 1874. Waite at the time was serving as counsel for the U.S. government in an arbitration proceeding in Geneva. He had been an Ohio lawyer who had some involvement with Republican politics and was known to have an incorruptible reputation. But he was virtually unknown. After Grant appointed him on January 19, The Nation said that the President had "avoided choosing any first-rate man," and that Waite "stands in the front rank of second-rate lawyers." 109

Aware of his obscurity, Waite determined to make a good first impression, paying social calls on the Justices after arriving in Washington before his formal swearing-in and delaying writing an opinion for some time after ascending to the bench. Three weeks into the position he wrote his wife,

Every day in Court hard at work and harder at work outside of the Court room. It is all new and I have adopted the plan of going to the bottom of all new questions so that when I once understand it fully, I shall not have to look it up again. ...

... [W] e had a great many cases submitted to us last week. I had to examine all of them and prepare myself to state intelligently the questions to be decided. . . . I went to Court with nearly all the cases prepared for presentation and Judge Miller and Judge Davis . . . both complimented me on my dispatch of business. I have as yet read no opinions, in Court, and I have prepared none. When I pass that test successfully I shall put myself where I have nothing more to fear, if I keep up to my standards. ${ }^{110}$

The letter makes clear that the custom of the Chief Justice presenting cases to be discussed at the Court's conference remained in place as Waite succeeded Chase. It also reveals Waite's awareness that some members of the Court viewed his appointment with skepticism. Miller wrote after three weeks that he found Waite "pleasant, a good presiding officer," but "mediocre." time, said that Waite was "gentlemanly in his manners," but "how much of a lawyer he is remains to be seen," adding that "[h]e may turn out to be a Marshall or a Taney, though such a result is hardly to be expected." ${ }^{112}$ Mindful of his inexperience and obscure reputation,

${ }^{109}$ NATION, Jan. 22, 1874, quoted in MAGRATH, supra note 106, at 17.

${ }^{110}$ Letter from Morrison R. Waite to Amelia Waite (Mar. 22, 1874), quoted in MAGRATH, supra note 106, at 105-06.

${ }^{111}$ Letter from Samuel F. Miller to William P. Ballinger (Mar. 21, 1874), quoted in FAIRMAN, Mr. JUSTICE Miller, supra note 77, at 349.

${ }^{112}$ Letter from Stephen J. Field to Matthew P. Deady (Mar. 16, 1874), quoted in MAGRATH, supra note 106, at 107. 
Waite proceeded cautiously, writing only five opinions in his first Term; the other Justices each produced between seventeen and thirty opinions in the same time period. ${ }^{113}$

Once Waite became more comfortable, he took on a large share of the Court's work. Between 1870 and 1890, the Court's workload increased significantly, largely as a result of the growing number of nonconstitutional cases that lower courts certified. Independent federal circuit courts of appeal were not established until $1891 .^{114}$ Waite responded to the situation by increasing his own assignments, at one point taking over the circuit duties of Justice Ward Hunt after Hunt suffered a stroke in $1878 .{ }^{115} \mathrm{He}$ also took on a large number of opinions in cases he considered significant and assigned other opinions to his more gifted colleagues, bypassing Justices, such as Clifford, Swayne, Davis, and Hunt, who were either disinclined to write opinions or whom Waite thought inept. ${ }^{116}$

Waite's administrative skills eventually came to be appreciated by Miller, who had continued, throughout the 1870 s, to regard Waite as undistinguished. In an 1875 letter, Miller had complained that "I can't make a great Chief Justice out of a small man," noting that Waite was assigning cases to Clifford and Swayne, whose old age and lack of competence resulted in their "writ[ing] opinions in which their garrulity is often mixed with mischief." ${ }^{117}$ He wrote in the same vein four years later, stating that Waite lacked the "firmness and courage" to insist that his colleagues write shorter opinions. ${ }^{118}$ Waite wanted "to be popular," Miller suggested, and had "no conception" of "what is becoming" to the Court. ${ }^{119}$ In 1885, however, when Waite fell ill and

${ }^{113}$ See FAIRMAn, PART TwO, supra note 105, at 131 (noting that Miller wrote thirty opinions, Swayne and Strong twenty-seven, Hunt twenty-four, Bradley twenty-three, Field twenty-one, Davis nineteen, and Clifford seventeen).

${ }^{114}$ See MAGRATH, supra note 106, at 266-67 (discussing the Supreme Court's heavy workload prior to the establishment of the circuit courts of appeal).

${ }^{115}$ Id. at 268-69.

${ }^{116}$ Between 1874 and 1881, Waite wrote fourteen opinions in constitutional cases he considered significant. He assigned eleven such cases each to Miller and Field, ten to Strong, seven to Bradley, and five to Justice John Marshall Harlan, who had joined the Court in 1877. He assigned only four opinions to Swayne, two to Davis, and one each to Clifford and Hunt; each of these four Justices was on the Court for the entire time period. MAGRATH, supra note 106, at 263.

${ }^{117}$ Letter from Samuel F. Miller to William P. Ballinger (Dec. 5, 1875), quoted in FAIRMAN, Mr. JUSTICE MiLler, supra note 77, at 373-74.

${ }^{118}$ Letter from Samuel F. Miller to William P. Ballinger (Oct. 29, 1879), quoted in FAIRMAN, Mr. JUSTICE Miller, supra note 77, at 408-09.

${ }^{119}$ Id. 
Miller, now the senior associate Justice, presided in his stead between January and March, Miller confessed that although "I always knew that he did a great deal more work than I . . . [,] what I suspected hardly comes up to the draft on his time as he performed these duties." ${ }^{120}$ On one occasion Miller complained to Waite that Bradley was not completing his opinions, saying that if he were "permanent C Justice" he would give Bradley no more opinion assignments until the situation was rectified. ${ }^{121}$ Miller's correspondence suggests that he had begun to appreciate some of the additional burdens that went with the chief justiceship: he urged Waite, when he returned, not to work as hard lest he break down. ${ }^{122}$

By Waite's death in 1888 his colleagues had come to appreciate both the importance of administrative skills in the chief justiceship and Waite's own abilities as a manager. Justice Samuel Blatchford captured that assessment in an 1886 letter to Waite in which he declared:

Your brethren alone, in the intimacy of the conference room, and the privacy of the arcana, know the skill, the patience, the uniform good temper, and the high sense of the dignity of the Court, which have marked the discharge of your duties. ${ }^{12}$

During Waite's tenure it had become clear that the Court's increased docket had created constant pressure on the Justices to dispose of cases, and that the speedy and effective dispatch of business fell primarily on the Chief. Not only was it important for Chiefs to present cases succinctly at conference and to assign opinions so as to ensure that they were passed upon and delivered in a timely fashion, but Chiefs regularly, as Miller noted in 1885, disposed of "practice motions, motions to dismiss for want of jurisdiction," and other summary matters, all of which involved written instructions to the Court's clerk. ${ }^{124}$ Waite, whose juristic abilities were clearly overshadowed by some of his colleagues', ${ }^{125}$ had nonetheless proved to be a distin-

${ }^{120}$ Letter from Samuel F. Miller to William P. Ballinger (Jan. 18, 1885) [hereinafter Miller-Ballinger Letter], quoted in FAIRMAN, MR. JUSTICE MILLER, supra note 77, at 391.

${ }^{121}$ Letter from Samuel F. Miller to Morrison R. Waite (Jan. 25, 1885), quoted in MAGRATH, supra note 106, at 273.

${ }^{122}$ MAGRATH, supra note 106, at 274.

${ }^{123}$ Letter from Samuel Blatchford to Morrison R. Waite (Nov. 29, 1886), quoted in MAGRATH, supra note 106, at 275.

${ }^{124}$ Miller-Ballinger Letter, supra note 120.

${ }^{125}$ Waite seemed aware of his limitations as a jurist. He wrote to Field on one occasion: "The difficulty with me is that I cannot give the reasons as I wish I could." Let- 
guished managerial Chief at a time when managerial skills had clearly become part of the job description of the Chief Justice.

\section{From Waite to Fuller: The Chief Justice as Manager}

The process by which Melville Weston Fuller succeeded to the chief justiceship after Waite's death in 1888 resembled that of Waite's nomination in that the designee was a comparative nonentity. When Fuller was appointed, the New York Herald commented that he was "so unknown that his page did not appear in the latest standard works of contemporary biography," and the Philadelphia Press suggested that "he was the most obscure man ever appointed Chief Justice." ${ }^{126}$ No previous nominee had had such little experience in state or federal governmental positions. Fuller's only public service had been a twoyear stint in the Illinois legislature, where he had unfortunately aligned himself with the antiwar faction of the Democratic Party, which was humiliated in the 1864 election. ${ }^{127}$ He was appointed because he was a friend of President Grover Cleveland, from Illinois (the only major state without representation on the Court at the time), and shared Cleveland's views on currency issues. ${ }^{128}$ He was reluctant to accept the position and did so primarily because he did not want to embarrass Cleveland. ${ }^{129}$

Like Waite, Fuller was aware of the talents of some of the members of the Court that he joined, and was aware that not all of them expected great things from him. Two years after his appointment he wrote to the Court's reporter that "with these old luminaries blazing away with all their ancient fires" there would be " $[\mathrm{n}]$ o rising sun for me" as an incoming Chief. ${ }^{130}$ But Fuller's relations with the four dominant Justices he confronted on coming to the Court-Miller, Field, Bradley, and Harlan-were excellent. Bradley, who on Fuller's

ter from Morrison R. Waite to Stephen J. Field (Apr. 28, 1882), quoted in MAGRATH, supra note 106, at 185. He wrote to Justice Gray on another: "Can't you tell me the secret of your style. I wish I had it." Letter from Morrison R. Waite to Horace Gray (Feb. 21, 1884), quoted in MAGRATH, supra note 106, at 185.

${ }^{126}$ Willard L. King, Melville Weston Fuller: Chief Justice of the United STATES 1888-1910, at 114 (1950).

${ }^{127}$ See id. at 54 (calling Fuller's time in the Illinois House "the greatest misfortune of his career"); see also id. at 115 (presenting a table of previous governmental posts held by Chief Justices from Jay through Vinson).

${ }^{128} I d$. at $105-08$.

${ }^{129} I d$. at $108-13$.

${ }^{130}$ Letter from Melville W. Fuller to Bancroft Davis (Jan. 18, 1890), quoted in JAMES W. Ely, JR., THE CHIEF JustiCeship OF Melville W. Fuller, 1888-1910, at 25 (1995). 
nomination had suggested that only a "happy accident" would make Fuller's appointment "admirable," seeking his advice. ${ }^{132}$ Miller, who died only two years after Fuller became Chief Justice, had by that time concluded that "Fuller was the best presiding judge that the Supreme Court had had within his time" and that "he was a most lovable, congenial man." ${ }^{133}$ Field, who from the early 1890s until his forced retirement in 1897 was increasingly erratic and irascible, was sufficiently won over by Fuller that he gave Fuller his proxy when Field had a brief illness in $1893 .{ }^{134}$ And Harlan, whom Fuller had disparaged on his appointment to the Court in 1877, became a close friend of the Chief Justice. ${ }^{135}$

None of those reactions to Fuller was based on his intellectual contributions to the Court. It became clear to Fuller's associates that although he was as interested as Waite in the efficient dispatch of Court business, ${ }^{136}$ and as prepared as Waite to take on a good percentage of the Court's opinions, ${ }^{137}$ he was a diffident and not alto-

${ }^{131}$ Letter from Joseph P. Bradley to Stephen J. Field (n.d.), quoted in Irving Schiffman, Melville W. Fuller, in 2 THE Justices OF THE United STATES Supreme COURT: THEIR LIVES AND MAJOR OPINIONS 715, 724 (Leon Friedman \& Fred L. Israel eds., 1995).

${ }^{132}$ See KING, supra note 126, at 131 ("Fuller won Bradley by asking his aid.... Bradley took the new Chief Justice under his care and constantly counseled him. Fuller was closer to Bradley than to any other Justice during the three years of their joint service.").

${ }^{133}$ Miller made this comment to Senator Shelby M. Cullom of Illinois. SHELBY M. Cullom, Fifty Years of Public SeRvice 241 (2d ed. 1911).

${ }^{134}$ See Letter from Stephen J. Field to Melville W. Fuller (Dec. 16, 1893), quoted in ELY, supra note 130, at 26-27 ("You can cast my vote in all the cases with your own ....").

${ }^{135}$ See KING, supra note 126, at 132 ("Although Fuller had opposed Harlan's confirmation, they had become great friends by the time of Fuller's appointment.").

${ }^{136}$ Fuller was greatly advantaged in that regard by the passage of the Circuit Court of Appeals (Evarts) Act of 1891, ch. 517, 26 Stat. 826, which created intermediate federal circuit courts of appeal and eliminated direct appeals to the Supreme Court from most decisions of the federal courts in diversity of citizenship cases. The result was a dramatic reduction in the Fuller Court's docket. In 1888 the Court had 1571 cases on its docket, in 1889, 1648, and in 1890, 1816. KING, supra note 126, at 148. Even in its most active Terms the Court could not dispose of more than 450 cases per year. Id. Although the resultant backlog of cases was not to be eliminated for several years, by the turn of the twentieth century, the backlog had been reduced from approximately 1100 to 300 cases a year. ROBERT J. STEAMER, CHIEF JUSTICE: LEADERSHIP AND THE SUPREME COURT 135 (1986). In addition, after the passage of the Evarts Act the Court heard fewer new cases. KING, supra note 126, at 151. In 1890 there were 623 new cases on its docket, in 1891, 383, and in 1892, 290. Id. For a slightly different count of cases, see ELY, supra note 130, at 42-43.

${ }^{137}$ Fuller wrote 840 majority opinions during his tenure (1888-1910). ELY, supra note 130 , at 36 . From 1888 through 1901, he wrote more opinions than any other Jus- 
gether successful opinion writer. One student of the Fuller Court called his prose style "verbose and diffuse," noting that " $[\mathrm{h}]$ is opinions were clogged with excessive quotations from other decisions" and that "[h] e rarely turned a ... memorable phrase." ${ }^{138}$ Another commentator stated that Fuller "was respected by his colleagues, but only for his personal qualities and his administrative competence, not his legal acuity or depth." ${ }^{139}$ Fuller "was not in any way the source of the ideas that gave [his] Court its place in history."

The same commentator, on noting that Fuller assigned himself comparatively few of the major opinions handed down during his tenure, ${ }^{141}$ suggested that there was "a very good reason" for his practice. ${ }^{142}$ "The issue," he felt, "was not simply one of rhetorical style, elegance, vividness, or clarity of exposition, though his opinions lacked these qualities." ${ }^{143}$ It was "instead one of logical structure. [Fuller's] writings suggest that he was not fully in command of the central ideas that so characterized the time. Fuller was in no position to lead" his Court. ${ }^{144}$

But it was clear that Fuller did lead his Court in another respect. As Holmes later put it, Fuller "had the business of the Court at his fingers['] ends, he was perfectly courageous, prompt, decided. He turned off the matters that daily called for action easily, swiftly, with the least possible friction." ${ }^{145}$ Fuller was also consistently tactful with his colleagues. Holmes told the story of interrupting an argument advanced by Harlan in conference one day by declaring, "[T] hat just

tice. KING, supra note 126, app. I at 339. After Oliver Wendell Holmes joined the Court in 1902 Fuller's output receded, but only in his last three Terms, when Fuller's health began to decline, was there a noticeable falloff. ELY, supra note 130, at 37. For additional evidence of this decline, see the table of Fuller Court opinions in KING, supra note 126, app. I at 339.

${ }^{138}$ ELY, supra note 130 , at 37.

139 Owen M. Fiss, Troubled Beginnings of THE MOdern STATE, 1888-1910, at 2627 (The Oliver Wendell Holmes Devise History of the Supreme Court of the United States, vol. 8, Stanley N. Katz ed., 1993).

${ }^{140} I d$. at 27.

${ }^{141}$ For evidence of Fuller's disinclination to assign himself opinions of the Court in important cases, see Brenner, supra note 39, at 146 (concluding that although Fuller was with the majority in twenty-seven out of thirty-five such cases, he assigned the opinion of the Court to himself in only four of them, the lowest percentage of all the Chiefs).

${ }^{142}$ FISS, supra note 139, at 28.

${ }^{143} I d$.

${ }^{144} I d$.

${ }^{145}$ Letter from Oliver Wendell Holmes to William L. Putnam (July 12, 1910), quoted in KING, supra note 126, at 334. 
won't wash," Harlan taking umbrage, and Fuller interjecting, "But I just keep scrubbing away" to defuse the tension. ${ }^{146}$ A study of "leadership" among Chief Justices found that Fuller did

what a successful manager must do: pay attention to matters large and small. In the latter he cultivated friendship by looking to the welfare of each justice, inviting new appointments to a special dinner, deferring frequently to the opinion of others, and originating the custom of requiring each justice to greet and shake hands with every other justice before they began the day.... [He also] carr[ied] the heavy burden of writing more than his share of opinions ....

Fuller's skills extended to the assignment of opinions: Holmes wrote a judicial colleague in 1930 that "his grounds were not always obvious, but I know how serious and solid they were and how remote was any partiality from his choice." "As "As a presiding officer," Holmes told Felix Frankfurter, "Fuller was the greatest Chief Justice I have ever known." ${ }^{149}$

The managerial functions of the Chief Justice at the close of the nineteenth century continued to take place against a backdrop in which the Court's protocols remained strikingly informal. Through Fuller's tenure the Justices continued the practice of not circulating assigned opinions before they were read in conference prior to being announced in Court. Only in exceptional cases-those perceived as having widespread public implications and provoking division within the Court-did the Justices depart from this practice. ${ }^{150}$

The Court's practices with respect to the assignment of opinions were equally informal. As we have seen, during the Chase and Waite

${ }^{146}$ KING, supra note 126, at 290.

${ }^{147}$ STEAMER, supra note 136 , at 134.

${ }^{148}$ Letter (draft) from Oliver Wendell Holmes to Stephen A. Day (1930), quoted in KING, supra note 126 , at 334

149 KING, supra note 126, at 290.

${ }^{150}$ For a rare example from the Waite Court where draft opinions were circulated as part of the Justices' deliberations, see FAIRMAN, PART TWO, supra note 105, at 365; MAGRATH, supra note 106, at 182. The case in question was Munn v. Illinois, 94 U.S. 135 (1877), which involved the constitutionality of legislation regulating grain elevators.

The usual practice of noncirculation was in place for the opinion in Railroad Co. $v$. Fort, 84 U.S. 553 (1874). The decision was announced on January 5, 1874, and Justice Miller wrote his brother-in-law almost two weeks later that he "received yesterday for the first time the opinion in the case," and that he was surprised to see that the author of the opinion, Justice David Davis, had decided the case on its facts, and therefore, in Miller's view, the opinion "can be of little value to any one." Letter from Samuel F. Miller to William P. Ballinger (Jan. 18, 1874), quoted in FAIRMAN, PART TwO, supra note 105 , at 104-05. 
Courts the Chief Justice apparently assigned opinions when he was in the majority, but when he was among the dissenters the opinion was assigned by a caucus of the majority Justices. Fuller clearly assigned opinions when he was in the majority as well, ${ }^{151}$ but there is also evidence that on occasion he assigned opinions when he had dissented. ${ }^{152}$

In sum, the nineteenth-century legacy of the Chief Justice's internal powers revealed those powers to be considerable. As the Court evolved from one in which the distribution of opinion assignments was uneven to one in which Justices had an expectation of sharing equally in the writing of opinions, the Chief's role in opinion assignments became a more delicate one. Part of Waite's and Fuller's success with their colleagues came from the tactful manner in which they met expectations while preserving their goal of ensuring that dilatory or less competent Justices received fewer assignments. In addition, as the Court's docket increased, the Chief's role in managing that docket, which included setting the agenda for conferences and disposing of the Court's more summary actions, took on a greater importance. By Waite's tenure, the Court's "adjourned Term" had become a permanent feature of its calendar, so that the Justices met in Washington from October through May, with circuit riding reserved for the summer months. After 1891, the Justices' circuit-riding obligations ceased, and the presence of the federal circuit courts of appeal reduced the volume of the Court's business, but Chiefs continued to be faced with backlogs of cases. For all of Waite's tenure, and all but the

${ }^{151}$ See, e.g., Letter from Stephen J. Field to Melville W. Fuller (Mar. 8, 1896), quoted in KING, supra note 126, at 224 ("I return to you the enclosed memorandum of the cases assigned to the different Justices made yesterday. I do not care to retain any memorandum of assignment of cases where none are assigned to myself. I do not know and shall not ask the reason that no cases have been assigned to me within the past six months."). Field had been failing in the mid-1890s, although he was determined to stay on the Court, and Fuller had assigned him fewer and fewer cases. KING, supra note 126 , at 222-24.

${ }^{152}$ On May 19, 1910, Fuller wrote a letter to Holmes asking him to take over the writing of an opinion previously assigned to Justice David Brewer, who had died soon after the assignment. "I am compelled to ask you if you can write this case," Fuller said. "The vote was Lurton \& C.J. to affirm \& Day, Holmes, McKenna, White, Brewer and Harlan to reverse." Letter from Melville W. Fuller to Oliver Wendell Holmes (May 19, 1910), quoted in FISS, supra note 139, at 23 n.6. The case was Dozier v. Alabama, 218 U.S. 124 (1910). When Holmes produced his opinion, the dissenters declined to file published opinions. Had current practice been followed, the assignment of the Dozier opinion would have fallen to Justice Harlan, the senior Justice in the majority. 
last years of Fuller's, this resulted in the Chief Justice taking on the largest number of opinions. ${ }^{153}$

The managerial powers of the Chief were accentuated by the fact that the Court's deliberative process remained comparatively informal throughout Fuller's tenure. Once opinion assignments were madetypically by the Chief, given Waite's and Fuller's pattern of infrequently dissenting-opinions were not circulated, except on rare occasions, before being read by the author in conference. This gave opinion writers considerable autonomy with their language and meant that writing an opinion was a greater opportunity to shape its impact than under a system in which drafts were circulated, and language potentially altered, in order to keep majorities intact. As a result, opinion assignments may have been more coveted than under the Court's current protocol. The correspondence about opinion assignments that has survived from the Waite and Fuller Courts suggests that Justices passed over in assignments were disappointed and that Chiefs took pains to create an impression of being fair-minded in their assignment decisions.

The comparative obscurity of Waite and Fuller at the time of their nominations, when added to the fact that each of them joined Courts featuring experienced senior Justices who were accustomed to exerting influence, may have contributed to the attention they paid to the managerial dimensions of their positions. At the same time, both Waite and Fuller, comparatively self-effacing individuals with strong personal relations skills, may have gravitated to the managerial aspects of the chief justiceship. One might compare the tactful responses of Waite to piqued outbursts by Field, ${ }^{154}$ or Fuller's mild suppression of

${ }^{153}$ On the length of the Court's Terms, see FAIRMAN, PART OnE, supra note 40, at 69 n.138 (indicating that between 1859 and 1867 the Court began its Terms in December, and that its average Term lasted about seventeen weeks, extending into April). In the 1868 Term, when Chase was in the fourth year of his chief justiceship, the Court began its "adjourned Term" practice, which consisted of taking up cases in October that had not been decided the preceding spring. Those "adjourned Term" sessions would continue until 1873, when Congress enacted a statute changing the official date of the Court's opening from December to "the second Monday of October." Act of Jan. 24, 1873, ch. 64, 17 Stat. 419. During Waite's tenure, the sessions that began in October typically lasted through the first half of May. FAIRMAN, PART ONE, supra note 40 , at $69 \mathrm{n} .138$.

For a discussion of the Circuit Court of Appeals (Evarts) Act of 1891, ch. 517, 26 Stat. 826, which ended the obligation of the Justices to ride circuit but did not have an appreciable effect on the Court's docket, see FISs, supra note 139, at 24-25.

${ }^{154}$ See MAGRATH, supra note 106, at 260 (reprinting and discussing Waite's letters to Field after Field had protested against not receiving an opinion assignment in United States v. Union Pacific Railroad Co., 91 U.S. 72 (1875)). Field had apparently taken of- 
Holmes's instinct to write every opinion he could, ${ }^{155}$ with the covert strategic behavior that characterized Chase's approach to internal issues during his tenure. By 1910 it had become clear that for a Chief to be internally effective, he needed to "manage" his colleagues.

Meanwhile, the norm of silent acquiescence seems to have remained in place, although its impact was reduced, especially under Waite's and Fuller's tenures, as Chiefs became more concerned with equalizing opportunities for their colleagues to write "opinions of the Court," especially in significant cases. The comparatively small amount of correspondence between Waite and Fuller and their colleagues about opinion assignments suggests that unless a Justice was aged or infirm, writing opinions for the Court was valued, and that issuing public dissents was less frowned upon than it had been during Marshall's tenure. It seems fair to say that although silent acquiescence continued to take place on the Court as it entered the twentieth century, the supposition that it functioned to enable "lazy, modest, and incompetent" Justices to avoid having to do much work was less credible than it may have been on the Marshall Court.

\section{TRANSFORMED PROTOCOLS AND THE CHIEF JUSTICESHIP}

The managerial dimensions of the chief justiceship have remained in place throughout the twentieth and twenty-first centuries. But the backdrop of the Court's business has undergone very significant changes since Fuller's time. The changes have been so radical, in fact, that Justices who served on the Fuller Court might have difficulty recognizing its twenty-first century institutional counterpart.

fense at Waite's suggestion that it made sense to assign the opinion to Davis, who was known as a critic of the railroad industry. In the second of the letters, Waite reminded Field that " $[\mathrm{t}]$ here was no doubt of your intimate personal relations with the managers of the Central Pacific," and "that you were dissatisfied with the manner of the argument on the part of the government," a sentiment which "might, unconsciously to you, find expression in the opinion." Letter from Morrison R. Waite to Stephen J. Field (Nov. 10, 1875), quoted in MAGRATH, supra note 106, at 260. Waite also noted that "[a]s for opinions in important cases, ... I think you fared better than [Davis] ... did at the last term." Id.

${ }^{155}$ See Letter from Melville W. Fuller to Mary Ellen Coolbaugh Fuller (Feb. 18, 1903), quoted in KING, supra note 126, at 291 ("The Nimble Holmes has got out his last-I delayed his progress for about a week but he deserved the obstacle \& is free and clear \& I suppose eager for more work."). Earlier Holmes had written to Fuller, "I am on my last [assigned] cases barring the one you told me not to write until further notice ...." Letter from Oliver Wendell Holmes to Melville W. Fuller (Feb. 5, 1903), quoted in KING, supra note 126, at 291. 
The present Court sits in its own building, with chambers for individual Justices, rather than in a room in the Capitol. Conferences are held in a room in the Court, rather than in a boardinghouse, a Capitol consultation room, or, as during Fuller's tenure, in the Chief Justice's house in Washington. ${ }^{156}$ Instead of doing most of their work in their homes and coming together only for oral arguments and conferences, Justices now have the opportunity to see their colleagues on a daily basis outside of the courtroom or conference room. Although not all take advantage of the opportunities for informal contact and exchange of ideas that their work environment offers, such opportunities do exist. One might say that the present Court's work environment more closely resembles that of the Marshall Court than the Courts on which Waite, Fuller, and their contemporaries served.

The opportunities afforded to Justices for a protracted exchange of ideas are matched in the current Court by the incentives for exchange that have been produced by its transformed protocols. The internal deliberative process of the current Court is substantially different, in a few respects, from that of nineteenth-century Courts. It is, simultaneously, a more formalized and a more collegial process. The transformations in that process-the protocol changes-since the nineteenth century have had a discernible effect on the internal powers of the Chief Justice. Nonetheless, those powers remain in place, making the nineteenth-century legacy of the chief justiceship still relevant.

Two protocol changes have been particularly significant. One is the virtual disappearance of the practice of silent acquiescence. Although that practice had lessened in significance once Chiefs such as Waite and Fuller adopted a more even-handed approach to the assignment of opinions, it was still possible, as late as the 1930s, for a Justice to have dissented from an opinion of the Court but not recorded that dissent. As late as the 1940s, the official United States Reports only identified the author of the "opinion of the Court" and those Justices who either filed concurring or dissenting opinions or who had themselves identified as either concurring in the majority result or dissenting. The current practice of listing the votes of all the Justices who participated in a case in the headnote to that case in the

156 ELY, supra note 130, at 39; KING, supra note 126, at 152. 
United States Reports did not begin until $1947 .{ }^{157}$ With the adoption of that protocol, silent acquiescence became a rare phenomenon. ${ }^{158}$

The publication of all the votes of the Justices in all cases was accompanied by another, equally significant, protocol change. Instead of "opinions of the Court" being assigned, prepared, and ultimately delivered without circulation, the circulation of drafts of all "opinions of the Court" became, in effect, mandatory. ${ }^{159}$ This change was not contemporaneous with the publication of votes; it seems to have been in place, perhaps in an incomplete version, during Holmes's and Brandeis's tenures on the Court. A letter Holmes wrote to Fuller in 1902, shortly after Holmes came on the Court, indicates that Holmes had an expectation that his "opinion of the Court" in the case of Otis v. Parker ${ }^{160}$ needed to be passed upon by all the Justices who were members of the majority in that case. ${ }^{161}$ But that was not the practice on the Fuller Court: Justices who were assigned "opinions of the Court" continued to prepare them on their own for delivery in conference. By the White Court, however, there is evidence that drafts of

${ }^{157}$ Technically, the United States Reports did not even begin listing Justices' positions that year. The first example of a listing of all of the Justices' votes in a headnote to a case appears in the first series of the ninety-second volume of the United States Supreme Court Reports, Lawyers' Edition. The case involved was Rodgers v. United States, 332 U.S. 371, 92 L. Ed. 3 (1947). The votes of individual Justices were not listed in the official United States Reports headnote for the Rodgers case.

${ }^{158}$ A version of silent acquiescence can still occur where a Justice has prepared a dissenting opinion and then is persuaded, or chooses for strategic reasons, to withdraw it. See Alexander M. Bickel, The UnPublished Opinions of Mr. Justice Brandeis (1957), for a number of examples of dissenting opinions that Brandeis suppressed, typically in exchange for language alterations in the majority opinion. Brandeis was able to do this with greater freedom under the Court's pre-1947 protocol (Brandeis retired from the Court in 1939) since, unless he was recorded as dissenting, his individual vote would not be made public. But even after 1947, a Justice can agree to join a majority opinion after having originally dissented, once he becomes satisfied with the opinion's language.

${ }^{159}$ I am including the qualifier "in effect" because there is no formal rule of the Court that opinions must be circulated before being formally issued, and circumstances such as the sudden illness or incapacitation of a Justice, or of the immediacy of particular decision (reportedly not all of the opinions in Bush v. Gore, 531 U.S. 98 (2000), were circulated among all of the Justices) might result in not all Justices having access to opinions. But there is clearly an expectation that in ordinary circumstances all Justices will have access to all opinions that may eventually be published.

160 187 U.S. 606 (1903).

${ }^{161}$ See Letter from Oliver Wendell Holmes to Melville W. Fuller (Dec. 28, 1902), quoted in KING, supra note 126, at 289 ("I have not heard from Harlan, Brewer, Shiras or Peckham J J as to ... Otis v. Parker. I suppose I am to do nothing until the next conference? Mr. J. Harlan to be sure said on the day that he received it that he had read it and I understood him to agree ...." (footnote omitted)). 
majority opinions were beginning to be circulated. Holmes complained in letters written in 1918 and 1920 that "the boys" were forcing him to tone down some of his vivid language. ${ }^{162}$ White sent Brandeis a comment on the latter's first opinion in 1916: "Very well done. Indeed fine!" ${ }^{\prime 63}$ But circulation was not mandatory, and when it occurred it sometimes had the effect of dissolving majorities that had existed at conference. ${ }^{164}$

If the practice of circulating drafts was still informal and occasional before $1947,{ }^{165}$ the protocol identifying the votes of all the Justices in all cases made it mandatory. Now all Justices who had joined an opinion of the Court were known: the language of that opinion was language they had subscribed to. In such circumstances it was inevitable that Justices would want to see the language of draft majority opinions before "signing on." The papers of Justices who served after 1947 are now filled with notations from colleagues indicating their assent to particular drafts, as well as memoranda raising questions and asking for changes.

${ }^{162}$ See Letter from Oliver Wendell Holmes to Frederick Pollock (Jan. 24, 1918), in 1 HOlmes-POllock LETTERS: THE CORRESPONDENCE OF Mr. JUSTICE HOLMES AND SIR FREDERICK POLLOCK 1874-1932, at 257, 258 (Mark DeWolfe Howe ed., 1941) ("The boys ... have badly cut down this week's [opinion]."); Letter from Oliver Wendell Holmes to Harold J. Laski (Nov. 17, 1920), in 1 HOLMES-LASKI LeTters: THE CORRESPONDENCE OF MR. JUSTICE HOLMES AND HAROLD J. LASKI 290, 291 (Mark DeWolfe Howe ed., 1953) ("The boys made me emasculate one [opinion] ....").

${ }^{163}$ Letter from Edward D. White to Louis D. Brandeis (n.d.), quoted in ALEXANDER M. BICKEL \& BENNO C. SCHMIDT, JR., THE JUdiCIARY AND RESPONSIBLE GOVERNMENT, 1910-21, at 604 n.167 (The Oliver Wendell Holmes Devise History of the Supreme Court of the United States, vol. 9, Paul A. Freund \& Stanley N. Katz eds., 1984).

${ }^{164}$ One example was the Arizona Employers' Liability Cases, 250 U.S. 400 (1919), which tested the constitutionality of an Arizona statute giving workers in hazardous occupations, who were covered by workmen's compensation, the option of seeking jury trials for their injuries under the statute, which provided for liability without fault on the part of the employer. After Holmes was initially assigned the opinion by White, he produced a draft opinion that generated four dissents, including one from White, and was eventually withdrawn for an opinion written by Justice Mahlon Pitney from which the same four Justices dissented. BICKEL \& SCHMIDT, supra note 163, at 586-91.

${ }^{165}$ Holmes's correspondence suggests that by the Taft Court (1921-1930), circulation of draft majority opinions was anticipated. See, e.g., Letter from Justice Holmes to Frederick Pollock (Nov. 26, 1922), in 2 HOLMES-POLLOCK LETTERS, supra note 162, at 106, 106 (indicating that "everybody [on the Court] seems to have misgivings" about a draft opinion in Pennsylvania Coal Co. v. Mahon, 260 U.S. 393 (1922), that he had circulated). In addition, STEPHEN W. BASKERVILle, OF LAWS AND LIMITATIONS: AN INTELLECTUAL PORTRAIT OF LOUIS DEMBITZ BRANDEIS 242-45 (1994), lists several cases in the 1920s in which Brandeis changed his position on cases after the Justices decided to abandon previously circulated "opinions of the Court." Baskerville relies on material in BICKEL, supra note 158, and Melvin I. Urofsky, The Brandeis-Frankfurter Conversations, 1985 Sup. CT. REV. 299, 309, for his case examples. 
The implications of these two protocol changes for the work of Justices have been quite significant. Whereas an assignment to write the "opinion of the Court" had been, alternately, a plum that a Justice coveted or the equivalent of forced labor, that assignment is now an exercise in keeping a majority together. The expectation that "opinions of the Court" would be circulated has meant that Chiefs, on assigning them, invariably need to consider the ability of the writer to retain that majority. There is thus an added dimension to the task of assigning opinions.

The new protocol also invited concurring and dissenting opinions. It confronted all the Justices, in every case, with justifications for a result that, on closer inspection, others might not agree with. Published dissents on the Waite and Fuller Courts had been low, and this tendency continued on the White Court. But by the Hughes and Stone Courts dissents were becoming more frequent, and by the 1980s dissents and concurrences had become so common that a group of political scientists attempted to analyze the "mysterious demise of consensual norms" on the Court. ${ }^{166}$ Despite that effort, it seems unlikely that more recent Courts have been less "consensual" than their predecessors. The transformation of protocols, which has ensured that all the votes of the Justices will be known and all majority opinions will be circulated in draft form, has created much stronger incentives for Justices to scrutinize language in opinions with which they are now publicly associated, and thus more incentives to respond to that language in separate opinions. In addition, whereas Justices as late as on the Vinson Court typically had only one law clerk to aid them with their research, law clerks have proliferated since Warren's tenure. When one adds computers to the mix, the production of a concurring or dissenting opinion in response to a circulated draft becomes a comparatively routine part of a Justice's job description.

Do these changes make a difference for Chief Justices? Have they served to render the nineteenth-century legacy of the Chief Justice's internal powers irrelevant? The short answer, despite the altered institutional context in which the current Court makes decisions, is no. The special seniority of the Chief remains, in the form of docket management powers, conference presiding powers, and assignment powers. The assignment of opinions has different implications now that the Court's protocols have changed from an informal "mooting" of

${ }^{166}$ Thomas G. Walker et al., On the Mysterious Demise of Consensual Norms in the United States Supreme Court, 50 J. POL. 361 (1988). 
cases, a norm of silent acquiescence, and no circulation of opinions prior to delivery to a more formal, routinized conference deliberation in which cases are discussed-and opinion assignments given out-on the basis of the seniority principle, and in which there is a clear expectation that draft majority opinions will be circulated to all the Justices. But the Chief's assignment power has, if anything, become more challenging and more important.

The protocol changes may have subtly affected the managerial skills associated with effectiveness as Chief Justice. In a deliberative process in which everyone takes responsibility for their votes, opinion writing, because of its collegial dimensions, becomes more burdensome, and even-handedness in the assignment of opinions consequently becomes more important. Chiefs now need to balance a sensitivity to varying talents and the symbolic aspects of assigning particular Justices to write in particular cases, factors Waite and Fuller felt they needed to consider, against a general expectation that opinion assignments will be equally distributed. In short, the Court's current protocols make opinion assignment a more delicate, and arguably a more important, power than it was for most of the Court's history.

In addition, the background of the Court's conferences has changed with the understandings among all participants that they will be held publicly accountable for votes, and that the conference votes, given the circulation protocol, are necessarily tentative. It is not clear, in the tenures of early nineteenth-century Chief Justices, how much skill in the presentation of cases scheduled for disposition at a particular conference mattered; it is not even clear that in the Marshall and Taney Courts there were definite sessions reserved for the disposition of cases, as opposed to an on-going caucus. But at least since Waite's tenure, the Chief's ability to present cases clearly and succinctly, and to foster an efficient dispatch of business, has been valued. Some Chiefs-White and Stone were singled out among the twentiethcentury Chief Justices-have tended toward loquacity and disorganization in the management of conferences. Charles Evans Hughes once said that "any virtues" he might have had as a Chief Justice "were due to my determination to avoid White's faults." "Very often," Hughes recalled, White "could not make up his mind and a favorite expression of his was, 'God help us.' ... [A]t times he would deliver an ex-

${ }^{167}$ Felix Frankfurter, Diary Entry (Apr. 25, 1947), in FROM THE DIARIES OF FELIX FrANKFurTER 313-14 (Joseph P. Lash ed., 1975) (quoting Charles Evans Hughes). 
temporaneous of oration of an hour's length" and "I would come home from Conference... with a strong feeling of frustration." 168 Stone, who had served as an Associate Justice under Hughes, chafed at the dictatorially efficient way in which Hughes ran conferences, and when he succeeded Hughes as Chief Justice in 1941 he tried "to focus discussion ... without being too much of a Czar." "169 The result, for the course of Stone's tenure, was very long conferences, a backlog of cases, and a proliferation of concurring and dissenting opinions.

In an atmosphere in which most Chiefs seek to foster consensus and the appearance of internal harmony against the backdrop of institutional changes that encourage Justices to scrutinize their colleagues' opinions carefully and to express themselves individually whenever they find themselves unsatisfied with a collegial product, getting the Court's business done without undue division, rancor, or delay takes on a high value, and the achievement of that goal largely falls on the Chief.

Finally, the protocol changes have an important jurisprudential dimension that has implications for the role of the Chief Justice itself. When one considers the silent acquiescence and noncirculation protocols against the backdrop of a jurisprudentially diminished status for judicial opinions, the individualized character of an "opinion of the Court"-itself a product, in part, of those protocols-becomes less of a deviation than it might appear from the principle that judicial opinions should reflect, rather than create, law. If an "opinion of the Court," regardless of the number of years in which it has been in place, is always susceptible to being shown as "demonstrably erroneous," and thus without any precedential weight, it would seem to matter less whether the opinion is the considered judgment of nine Justices or the product of just one. In this jurisprudential context, the deviationist quality of one-judge "opinions of the Court," not circulated to colleagues, whose dispositions are silently acquiesced in by Justices who did not vote for them, can be seen as a product of a quite different theory of the role of a judge. An "opinion of the Court" whose reasoning is the product of only one Justice seems obviously deviationist if judicial interpretation is equated with lawmaking, and the role of a judge is not so much to discern and apply a finite body of legal principles as to persuade others that his particular application of

$168 I d$.

${ }^{169}$ Letter from Harlan F. Stone to D. Lawrence Groner (Aug. 17, 1941), quoted in Peter Graham Fish, The POLITICS OF FEDERAL JUdiCIAL AdMINISTRATION 259 (1973). 
legal sources to resolve a controversy is faithful to those sources, analytically cogent under conventional professional standards, and culturally resonant. Put another way, the assumption that "law" cannot be thought of as wholly independent of the opinions of judges creates burdens on judicial opinion writers that an older assumption, reflected in the proposition that judicial opinions were merely evidence of the law, does not.

Given the burdens of persuasion that a modernist jurisprudential theory of the judge's role imposes on judicial opinion writers, one would expect commentators on a Court's work product to pay greater attention to the reasoning of opinions, and thus to be more mindful of the extent to which that reasoning was endorsed by individual members of the Court. One would expect specialist observers of the Court's opinions to be interested in just how each Justice voted in a case, and whether a Justice joined an opinion of the Court or wrote separately, because that information signals whether a Justice has subscribed to the Court's reasoning. With this expectation in place, silent acquiescence becomes unpalatable, and the Court's own headnotes to its opinions have now eradicated the practice. Further, circulation of opinions becomes imperative, because an "opinion of the Court" is no longer taken to be mere evidence of the law, but, notwithstanding its status as a judicial gloss, the practical equivalent of "the law" governing a particular set of issues.

In short, once the idea that judges are a species of lawmakers, and their interpretations more like the functional equivalent of "the law" rather than mere evidence of it, evolved to a position of orthodoxy in American jurisprudence, it was inevitable that the Court's protocols of silent acquiescence and noncirculation would be replaced by full disclosure of all the Justices' votes in all cases and mandatory circulation of drafts of "opinions of the Court." This means that since the 1950s, Chief Justices have exercised their agenda-setting and assignment powers knowing that whatever the outcome of dispositional votes in conference, those votes are necessarily tentative, because every member of the Court will typically be required to sign on to one set of justifications for a disposition. ${ }^{170}$ The protocol changes, in sum, have cre-

${ }^{170}$ It is of course possible for a Justice to dissent, or more rarely to concur, without opinion, or to indicate that he does not join a portion of an "opinion of the Court." But that practice, at least when unaccompanied by any opinion of the Justice, is increasingly rare. I would hypothesize that if one were to chart the prevalence of "silent" dissents, they would be far more common before the Court's headnotes began to identify the votes of all the Justices participating in decisions. 
ated a whole new dimension to the disposition of cases and the assignment of opinions, and no member of the Court is in a better position to affect those matters than the Chief Justice.

\section{CONCLUSION}

The more one studies the evolution of the informal powers of the chief justiceship and considers the changing institutional setting in which those powers have been exercised, the more one senses that the Chief Justice is hardly just first among equals. The modern Chief, like his predecessors, has needed to be part facilitator and part autocrat, reminding colleagues that fostering the Court's reputation regularly involves the suppression of egos without being unduly overbearing in the process. But unlike most of his predecessors, he has had to deal with a process of collegial decision making which has enhanced transparency, and hence enhanced scrutiny and potential vulnerability, for its participants. The more one learns about the internal powers of the chief justiceship, the more one realizes that with that office comes greater opportunities to exert influence, and to fail to do so, than with the Court's other eight positions. 